\title{
Muş İli Özelinde Doğal Tarım ve Hayvancılığa Dayalı Sürdürülebilir Bir Ekonomik Gelişim
}

\section{A Sustainable Economic Development Based on Natural Agriculture and Livestock Breeding in Muş Province}

\author{
Ömer Arslan ${ }^{a, *}$ \\ ${ }^{a}$ Dr. Öğr. Üyesi, Muş Alparslan Üniversitesi, Mühendislik Mimarlık Fakültesi, Makine Mühendisliği Bölümü, 49250, Muş / Türkiye. \\ ORCID: 0000-0003-4190-5271
}

\section{MAKALE BILGİSİ}

\section{Makale Geçmişi:}

Başvuru tarihi: 17 Ekim 2017

Düzeltme tarihi: 03 Ocak 2018

Kabul tarihi: 18 Ocak 2018

Anahtar Kelimeler:

Doğal Tarım ve Hayvancılık

Muş Ovası

Sürdürülebilir Ekonomik Gelişim

SWOT Analizi
ÖZ

Muş ili, Türkiye'nin üçüncü büyük iç ovasına (Muş Ovası) ev sahipliği yapmaktadır. Bununla birlikte Malazgirt, Bulanık ve Liz ovaları da Muş ili sınırları içerisinde yer almaktadır. Başta Muş Ovası olmak üzere Muş’ta yer alan ovalarda şimdiye kadar konvansiyonel tarım yapılmadığından, bu ovalar kimyasal gübre ve ilaçlamalardan etkilenmemiş ve temiz kalabilmiştir. İlin ovaları dışında kalan toprakları dağlık veya engebelidir. Bu dağlık ve engebeli topraklarda mera alanları ağırlıktadır ve buralarda $\% 80$ oranında mera hayvancılığı yapılmaktadır. Dünyada ve ülkemizde sağlıklı beslenme konusunda gittikçe yükselen bir bilinçlenmeye bağlı olarak doğal gıdaya rağbet gün geçtikçe artmaktadır. Bu artan talebi karşılayacak toprak alanlarının sınırlı olmasından dolayı da doğal gıda fiyatları konvansiyonel gıdaya göre oldukça yüksektir. Ancak Muş ili bu iki potansiyelini pazarda iyi değerlendiremediği için Türkiye'nin sosyo-ekonomik açıdan en az gelişmiş kentlerinden biridir. Bu araştırmada, Muş ilinin doğal tarım ve hayvancılıktaki potansiyelini değerlendirebilmek için ilin geçmişten günümüze ekonomik gelişimiyle birlikte ilin SWOT analizi göz önünde bulundurularak tarım ve hayvancılığa dayalı sürdürülebilir ve katma değeri olan bir ekonomik gelişism için yapılması gerekenler tespit edilmeye çalışılmıştır.

\section{A B S T R A C T}

Muş has the third largest inland plain of Turkey (the Muş Plain) and the Malazgirt, Bulanık and Liz plains. These plains have remained virgin and unspoiled since no conventional agriculture has been applied to them. The territories outside the plains of the province are mountainous or hilly plains. In this mountainous and uneven terrain, pastureland areas are dominant and in these lands $80 \%$ grassfed animal breeding is made. Due to a growing awareness of healthy nutrition in the world and in our country, the demand for natural food is increasing day by day and natural food prices are considerably higher than conventional food because of the limited availability of land to meet this increasing demand of it. Since Muş could not evaluate these two potentials well in the market, it is one of the socio-economically least developed cities of Turkey. In this research, the SWOT analysis of the province and from the past to today economic growth of the province will be considered together in order to assess the potential of the added value sustainable economic development based on natural agriculture and animal breeding.

\section{Giriş}

Muş ili Türkiye'nin sayılı büyük ovalarından birine sahiptir ve bu ova şimdiye kadar konvansiyonel tarım yapılmadığı için kimyasal gübre ve ilaçlamalardan etkilenmeden temiz kalabilmiştir. Ayrıca Muş ili 302.215 büyükbaş ve 1.021.142 küçükbaş hayvan sayısıyla, Türkiye'nin hayvan deposu olan Doğu Anadolu Bölgesi içinde önemli hayvancılık merkezlerinden birini oluşturmakta ve ilde $\% 80$ gibi yüksek bir oranla mera hayvancılığı yapılmaktadır (Muş Ovası
Tarım ve Hayvancılık Çalıştayı, 2017). Büyük bir doğal tarım ve hayvancılık potansiyeline sahip olan Muş ilinin, bu potansiyelini değerlendirerek kendine özgü bir tarım ve hayvancılık sektörü geliştirmesi gerekir.

Yurt içi ve yurt dışı pazar durumuna bakıldığında gıda sektöründe insanların beslenme ihtiyacından dolayı sürekli bir talebin olduğu ve bu nedenle de bu sektörde arz rekabetinin fazla olduğu görülmektedir. Bu durumun bir sonucu olarak teknoloji, tarımsal mekanizasyon, her türlü

\footnotetext{
* Sorumlu yazar/Corresponding author.

e-posta: oyusufoglu@ hotmail.com
} 
kimyasal ilaç ve gübre kullanılarak tarımsal verimliliği yüksek ve doğal olmayan ürünler elde edilmekte ve bu ürünler işlenmemiş, yarı işlenmiş veya tam işlenmiş bir şekilde pazarlanmaktadır. Bu alanda çoğunlukla büyük bir rekabet vardır ve bu rekabette ana strateji; tarımsal ve hayvansal üretimi düşük maliyetle gerçekleştirerek başlangıçta rakiplere göre düşük fiyatla pazarda mal satmak ve ardından da etkin bir tanıtımla markalaşarak zamanla pazarda yer edinmektir. Ancak Muş ilinin sahip olduğu sert karasal iklim ve kış mevsiminin uzunluğu, bu tür yüksek verimliliğe dayalı tarım ve hayvancılığın yapılabilmesine imkân vermemektedir. Bundan dolayı Muş, konvansiyonel gıdaya dayalı ekonomik gelişim stratejisi için uygun bir il değildir. Ayrıca doğal olmayan tarım, çevreyle barışık olmayıp toprağın yapısında tahribata neden olduğundan sürdürülebilir de değildir. Doğal gıda insan için daha sağlıklı ve çevreyle barışık olarak elde edildiğinden gıda sektöründe doğal gıda üretimine yönelik rekabet daha azdır. Çünkü dünyada tarımsal arazilerin çoğu yılar içinde kimyasallarla kirlenmiş olduğundan organik tarımsal ekim alanları sınırlıdır ve bu alanların organik tarıma elverişli hale getirilmesi oldukça zor ve maliyetlidir. Oysa Muş Ovası'nda geçmişte konvansiyonel tarım neredeyse hiç yapılmadığından, herhangi bir masraf yapılmadan ve çaba harcamadan organik gida üretimi rahatlıkla yapılabilir. Bu durum ilin ekonomik gelişimi için büyük bir potansiyel vaat etmektedir. $\mathrm{Bu}$ potansiyeli etkin bir şekilde değerlendirebilmek için özelikle mal üretiminin her aşamasının doğallığına riayet edilmelidir. Buna ek olarak üzerinde durulması gereken diğer bir önemli husus da doğal gıdada önemli bir yeri olan meracılığa dayalı süt ve et ürünleri konusunda Muş'un büyük bir potansiyele sahip olmasıdır. Meracılığa dayalı süt ve et ürünleri konusunda iyi bir tanıtım ve pazarlama stratejisiyle doğal gida konseptinde farkındalık oluşturulabilir. Ayrıca bölgeye özgü ürünlerin coğrafi işaret ve tescilleri yapılarak etkin ve hesaplı bir tanıtım ve reklam stratejisiyle ürünlerin bilinirliliği sağlanır ve doğru bir pazarlamayla nitelikli bir gelişim temin edilirse gıda sektörü ilde beşeri sermaye birikimini sağlayabilir. Bu durum, Muş ekonomisinin diğer sektörlerde de istenilen gelişimi sergilemesi için bir lokomotif işlevi görebilir.

$\mathrm{Bu}$ çalışmanın birinci bölümünde doğal tarım ve hayvancılığın kavramsal çerçevesi, sürdürülebilir tarım için organik tarımın gerekliliği ve Muş ili hakkında genel bilgiler verilmiş, ikinci bölümde ilin geçmişten günümüze ekonomik gelişim ve sanayileşme çabaları konusuna değinilmiş, üçüncü bölümde ildeki aktif sektörlerin envanteri çıkarılmaya çalışılmış, dördüncü bölümde Muş ilinin ekonomik potansiyel açısından SWOT analizi ve değerlendirilmesi ele alınmıştır. SWOT, İngilizce Strengths (güçlü), Weaknesses (zayıf), Opportunities (firsatlar) ve Threats (tehditler) kelimelerinin ilk harflerinden oluşturulan bir kelimedir. SWOT analiz tekniğiyle ilin güçlü (Strengths) ve zayıf (Weaknesses) yönleri tespit edilmeye ve kentin ekonomik gelişimi için var olan firsatlar (Opportunities) ve tehditler (Threats) saptanmaya çalışılmıştır. Beşinci bölümde ilin doğal tarım ve hayvancılık kapasitesinin korunması ve geliştirilmesi için hâlihazırda devam eden faaliyetler ile yapılması gereken çalışmalar ele alınmıştır. Altıncı bölümde doğal tarım ve hayvancılık ürünlerinden hak edilen katma değeri elde edebilmek için yöresel ürünlerin coğrafi işaretlerinin alınması, marka şehir bağlamında markalaşması ve pazarlanması konusunda yapılabilecekler ele alınmıș ve son olarak da yedinci bölümde bazı değerlendirmeler ve önerilerde bulunulmuştur.

\subsection{Doğal Tarım ve Hayvancılığın Kavramsal Çerçevesi}

Tarımsal ve hayvansal gidalar insan sağlığı perspektifinde aşağıdaki gibi sınıflandırılabilir. Tarımsal ürünler organik, organik olmayan konvansiyonel gida ve yabani olarak yetişen bitkisel flora ve meyveler olarak ayrılırken hayvansal gıdalar ise organik, konvansiyonel ve mera gidaları olarak sinıflandırılabilir. Organik ve organik olmayan gida arasındaki farklar ile organik gıdanın daha sağlıklı olduğu konusunda dünya kamuoyunda yeterli bir bilinçlenme mevcuttur (Liebhardt, 2003: 31-45). Gidanın organik olmasından, ürünün koruma ilaçları artıklarından arî olup sentetik hormonları, genetiği değiştirilmiş organizmaları ve kafamızda soru işareti oluşturan katkı maddelerini bünyesinde bulundurmadığı ve bunlara ek olarak üretiminin çevreyle barışık olduğu algılanmaktadır. Ancak hayvansal ürünlerde mera ve organik gıda arasındaki fark, bir başka deyişle mera ürünlerinin daha sağlıklı olduğu konusu kamuoyunda fazla gündeme gelmediği için yeterince bilinmemektedir. Bilim dünyasında son dönemlerde yapılan çalışmalar ve gelişmiş ülkelerde, özellikle ABD'de, bilinçli tüketicilerin bu konudaki faaliyetleri sonucunda mera eti, süt ürünleri ve diğer mera ürünlerin besleyicilik ve sağlık açısından, organik fakat sınırlı bir alanda ve tahılla beslenen hayvanlardan elde edilen gidalara göre daha üstün olduğu dile getirilmektedir (Eatwild, 2017). Doğal olarak yetişen bitki florasının büyük kısmı mera ve ormanlık alanların fazla olduğu yerlerde bulunmakta, bu ürünler mevsimsel olarak mutfaklarda yer almakta ve bazen de alternatif ilaç olarak çeşitli hastalıkların tedavisinde kullanılmaktadır. Örneğin Muş ilinde doğal semizotu, kenger, hiso, nisan, yabani pancar otu, çağ bitkisi, uçkun, güllük, kuş konmaz, meyan kökü vb. bitkiler; alıç, kızılcık, yabani erik, kuşburnu gibi çeşitli yabani meyveler bölge halkı tarafından bilinmekte ve tüketilmektedir. $\mathrm{Bu}$ ürünler için nitelikli ve sertifikalı markalar oluşturulabilir. Mera ürünlerini ABD'de gündeme getirme konusunda öncü kişilerden biri olan Jo Robinson, ödüllü kitabında (2013) insanoğlunun şu anda tükettiği birçok meyve-sebzenin yabani hayattan devşirilerek göze daha hoş gelme ve daha yenilebilir bir hale getirilme hikâyesini hatırlatmaktadır. Buna ek olarak mutfağımızda her gün tüketilen bu popüler gıdaların asıllarında bulunan birçok vitamin, mineral, protein, lif ve faydalı yağ asitlerini kaybetmiş olduğunu; yabani sebze ve meyvelerin sağlık açısından daha üstün olduğunu dile getirmektedir. Muş'a has bu tür birçok yabani gıda coğrafi işaretleri alınarak pazarlanabilir hale rahatlıkla getirilebilir. Fakat biz bu kısımda sağlık açısından organik ürünler kadar bilinmeyen mera ürünlerine odaklanacak ve bu konuda ortaya atılan argümanları özetleyerek mera ürünlerinin insan sağlı̆̆ açısından hayati önemini ve ekonomik potansiyelini ortaya koymaya çalışacağız.

Besi eti ve mera eti karşılaştırıldığında, meralarda yetişen sığır, kuzu ve keçide daha az toplam yağ, doymuş yağ, kolesterol ve kalori olduğu görülür. Örneğin Rule vd.'nin (2002: 1202-1211) bulgularına göre, merada yetişen sığırdaki toplam yağ miktarı derisiz tavukgöğsü, vahşi geyik ve Kanada geyiğindeki yağ miktarıyla aynıdır. Bu da, özellikle gelişmiş ve gelişmekte olan ülkelerde baş gösteren 
epidemik obezitenin önlenmesine büyük katkı sağlayacaktır. Geviş getiren bir hayvan meradan alınıp tahılla beslendiği zaman birçok değerli besleyici maddeyi kaybeder. Mera eti, tahılla beslenen hayvanın etinden $E$ vitamini, $C$ vitamini ve B vitaminleri gibi vitaminler; kalsiyum, magnezyum ve potasyum gibi doğal mineraller; beta-carotene ve omega-3s ile Conjugated Linoleic Acid (CLA) gibi sağlığı destekleyici yağ asitleri açısından daha zengindir (Duckett vd., 2009; Kraft vd., 2008; Couvreur vd., 2006). Örneğin merada yetişen sığır eti \%7'lik bir Omega-3s oranına sahipken tahılla beslenen sığırlarda bu oran $\% 1$ civarındadır. Vücutta yağların birçok türü vardır. Omega-3s ve 6s gibibazı çoklu doymamış yağlar insanlar için önemlidir ve bu yağlar gidalardan alınmalıdır. Bilimsel deneylerde, omega-6s yağ oranının omega-3s yağ oranının 4 katını aşması durumunda insanların obezite, diyabet, ateşli hastalıklar ve kanser gibi birçok hastalığa yakalanma riskinin arttığı ve sağlık sorunlarının yaşandığı tespit edilmiştir (Massiera vd., 2010; Simopoulos, 2002). Yapılan araştırmalarda tahılla beslenen hayvanlarda omega-6 oranının omega-3'e göre 20 kat daha fazla olduğu tespit edilmiştir. Merada yetişen sığırda ise bu oran 3 katıdır. Merada yetişen hayvansal ürünlerdeki Omega-3s miktarlarının fazlalığı yeşil otlardan kaynaklanmaktadır. Çünkü Omega-3s alg ve yeşil yaprakların kloroplastlarında oluşur. Buradaki yă̆ asitlerinin \%60'1 omega-3s'dir (Duckett vd., 1993: 20792088). Bu oranlar meralarda otlayan veya tahılla beslenen bütün büyükbaş ve küçükbaş hayvanlar için geçerlidir. Sonuç olarak mera ürünleri sağlık için faydalı omega-3 ve CLA gibi bütün yağlar açısından zengin; hastalıklarla ilişkili yağlar açısından ise fakirdir (McAfee vd., 2011: 80-89). CLA insan sağlığı için çok önemli olup kanser riskini, şişmanlığı, şeker hastalığını ve birçok bağ 1 şıklık bozukluğu hastalığını azaltan önemli bir maddedir (Ip, vd., 1994:10501054). Örneğin hayvanlar üzerinde yapılan araştırmalarda diyetteki yüzde $0.05^{\prime}$ lik küçük bir CLA artışının kanser tümörünü \%50 oranında azalttığı görülmüştür. Ayrıca Aro ve arkadaşları (2000: 151-157) CLA'nın göğüs kanseri riskini \%60 azalttığını tespit etmişlerdir. Buna ek olarak Dhiman ve arkadaşları (1999: 2146-2156) günlük gerekli CLA miktarının mera hayvanından elde edilen bir bardak süt, yaklaşık $30 \mathrm{~g}$ peynir ve bir parça et tüketilerek karşılanabileceğini ve bu durumun kanser riskini azalttığını belirtmişlerdir. Süte göre daha besleyici olan mera yoğurdunu da günlük diyetimize eklediğimizde kanser riski daha da azalacaktır. Yoğurdun bu bilimsel çalışmada yer almamasının nedeni ABD gibi birçok gelişmiş ülkede yoğurdun yaygın olmaması ve tüketiminin sütten daha az olmasındandır. Omega-3s yağ asitleri, kalp ve beyne faydalı olmanın yanı sıra kanseri önleyici bir yağ asidi olarak vücuttaki her hücre ve sistem için hayati öneme sahiptir (Bagga vd., 2002; Simopolous ve Robinson, 1999; Siscovick vd., 1995). Bilindiği gibi E vitamini kalp krizini ve kanser riskini azaltmanın yanı sıra etkili bir antioksidan olarak yaşlanmayı geciktirme özelliğine sahiptir.

Hayvanların organik veya organik olmayan tahılla beslenmelerinin yukarıdaki besleyicilik değerlerini değiştirmediği, besleyicilik değerlerinin hayvanların taze otlaklarda yetişmesiyle doğru orantılı olarak arttığı iddia edilmektedir (Robinson, 2004). Fakat organik olmayan besicilikte, üretimin düşük maliyetle artırılması amaçlandığından, yemler açısından da sorun yaşanmaktadır. Birçok gelişmiş ülkede konvansiyonel hayvancılıkta kullanılan yemler, hükümet sübvansiyonlarıyla düşük fiyatta tutulan, genetiği değiştirilmiş suni tahıl ve soyadan oluşmaktadır. Ayrıca buralarda maliyetin daha fazla düşürmesi için besi hayvanları belediye çöpleri, bayat hamur ürünleri, tavuk tüyleri ve şeker gibi yan ürün yemlerle de beslenmekte ve bundan dolayı bu hayvanlar organik olarak yetişen hayvanlara göre daha fazla ilaca gereksinim duyabilmektedirler. Bütün bunlara ek olarak mera hayvanları düşük stresli bir hayat sürdükleri ve dolayısıyla sağlıklı oldukları için kimyasal katkı maddeleriyle desteklenme, antibiyotik veya diğer ilaçlarla tedavi edilme gereksinimi duymazlar. $\mathrm{Bu}$ antibiyotiklerin bir kısmı insanlarda kullanılanlarla aynıdır. $\mathrm{Bu}$ ilaçlar besi hayvanlarında fazla kullanıldığında bakterilerin direnç geliştirmesine sebep olmaktadırlar. İnsanlar bu hayvanların ürünlerini tükettiğinde bu yeni dirençli bakterilerle enfekte olmaktadırlar. Bugün ABD'de üretilen antibiyotiklerin \%70'nin konvansiyonel hayvan yetiştiriciliğinde kullanılması tehlikenin boyutunu açıkça göstermektedir (Mailhes, 2011).

Modern tarım, hayvancılık için tahılla beslenme üzerinde durarak üretimi artırmıştır ve tahıllar omega-6s yağlar açısından zengindirler. Bu yüzden saldırgan, sanayileşmiş tarım yönetim teknikleri kırmızı ette omega-3s yağ miktarını azaltmıştır. Modern tarımsal ürünlerde genellikle omega-3s seviyesi oldukça düşüktür. Paleolitik toplumlar ve günümüz toplumları üzerinde yapılan araştırmalar gösteriyor ki insanın vücut doğası bugünkü diyetten çok daha az doymuş yağ asitlerine uygun niteliktedir. Biz tahılla beslenen hayvansal ürünlerden mera ürünlerine geçiş yaptığımızda atalarımızın diyetine geri dönüyoruz demektir. Otlarla yetişen hayvanların ürünlerini yediğimizde vücudumuzun her sistem ve hücresi daha iyi çalışacaktır (Robinson, 2004; Mercola, 2014).

Balık genellikle mera etinden daha yağsız bir gıda olarak tercih edilip, ağırlıklı olarak omega-3s yağı için iyi bir kaynak olarak bilinmektedir. Sorun şu ki fosil yakıtlardan enerji üretimiyle çevreye salınan zararlı madde ve gazlar, sanayi ve birçok hizmet atıkları deniz ve gölleri kirlettiğinden balık ve su ürünlerinde cıva ve benzeri birçok ağır metal oranı gittikçe artmaktadır. Bilindiği gibi cıva sinir sistemi ve böbrekleri tahrip etmekte; hatta küçük bir miktarı bile doğmamış bebekler ile 0-6 yaş arasındaki çocukların beyin gelişimini olumsuz etkileyebilmektedir. Bunun sonucunda tüketiciler, bazı deniz ve göllerdeki balık tüketiminin insan sağlığına zararları konusunda uyarılmaktadır. Örneğin ABD Gıda ve İlâç Kontrol Dairesi (FDA) ve Çevre Koruma Ajansı(EPA) birlikte hazırladıkları uyarılarda halkın Meksika Körfezinden avlanan kiremit balığ1, köpekbalığ1, kılıçbalığı ve iri uskumruyu tüketmemesi gerektiğini, çünkü bu balıkların yüksek miktarda cıva içerdiklerini belirtmekte, tüketicilerin bazı balıkları az yemeleri gerektiğini ve halkın yörelerine ait nehir ve göllerden gelen balıkları tüketirken su ürünleri uzmanlarının balıklara ilişkin uyarılarını dikkate almaları gerektiğini vurgulamaktadırlar (FDA, 2017a;FDA, 2017b). Birçok ülke için balıktaki cıva ve diğer ağır metaller konusunda uyarılar içeren buna benzer bilimsel çalışmalar yapılmaktadır (Örneğin, Jarup, 2003; Tuzen, 2009, Zhu vd., 2016). Diğer önemli bir husus da mutfaklarında balık yeme kültürü olmayan veya balığı sevmeyen birçok kişi için mera 
etinin omega-3s yağları açısından iyi bir seçenek olabileceğidir.

Sonuç olarak merada yetişen hayvanlardan elde edilen et, yumurta ve süt ürünlerini tüketmeyi seçtiğinizde hayvanların refahının gelişmesine, çevre tahribatının önlenmesine, küçük ölçekli çiftçilerin geçimine ve sürdürülebilir kırsal yaşamın devamına katkı sunmanın yanı sıra ailenize mümkün olabilecek en sağlıklı ve lezzetli gıdayı sunmuş olursunuz. Yukarıda izah edilen argümanlar dikkate alındığında mera gıda ürünlerinin öneminin gündeme gelerek tartışılması ve en sağlıklı gıda seçeneği olarak yakın gelecekte kabul görmesi kaçınılmazdır. Bu ürünlerin hem ulusal hem de uluslararası ölçekte kısa zamanda büyük bir pazarı olacak gibi gözükmektedir. $\mathrm{Bu}$ durumu doğru değerlendirip stratejik bir plan dâhilinde gerekli atılımları yapanlar, bu pazarda markalaşacakları için kazançlı çıkacaklardır.

\subsection{Muş İline Genel Bakış}

Türkiye'nin doğusunda yer alan Muş kenti, karasal iklimi ve 408.728 nüfusuyla sosyo-ekonomik açıdan ülkenin geri kalmış şehirlerinden birisidir (TÜİK ADNK, 2015). Muş, sanayileşme göstergeleri bakımından da son sıralarda yer almaktadır (Sanayi Genel Müdürlüğü, 2016: 1029-1043). Ekonomideki geriliğin nedenleri olarak; yeterli tarımsal mekanizasyona dayanmayan tarımsal üretimin ilde egemen olması, gelişimin lokomotifi olan orta ve büyük ölçekli devlet yatırımlarının geçmişte yapılmaması, yetersiz sermaye birikimi, yetişmiş kalifiye eleman eksikliği, nitelikli girişimci sayısının yetersizliği, iklim koşullarının zorluğu, doksanlı yıllardan itibaren baş gösteren terör sorunu, yeraltı kaynaklarının yeterince ortaya çıkarılmayışı ve nitelikli nüfus ve var olan sermayenin gelişmiş batı illerine göç etmesi gösterilebilir. Ayrıca son çeyrek asırda eğitim ve gelir seviyesi yüksek bilinçli tüketicilerin, sağlıklı beslenme talebine hitap eden ve gittikçe büyüyen doğal gıda pazarının öneminin farkına varamaması ve bu pazara uygun ürünlerin doğal gıda markası altında pazarlanmaması yaşanan olumsuzluklar arasındadır.

Muş halkının büyük kısmı kırsal alanda yaşadığı için, kentsel nüfus, Türkiye ortalamasının çok altında olup toplam nüfusun \%37,9'unu oluşturmaktadır. Hâlbuki kent merkezlerinde yaşayan nüfus ortalaması Türkiye'de \%91,3 tür (TÜİK, 2013). Muş’ta dağlık ve engebeli arazilerde mera alanları oranı yüksek, orman alanları oranı ise düşüktür. $\mathrm{Bu}$ durum bölgenin hayvancılık potansiyelini doğrudan olumlu yönde etkilediğinden doğal hayvan stokunun fazla olmasını sağlamıştır. Fakat tarımda büyük ölçüde geleneksel yöntemler kullanıldığı, teknoloji ve tarımsal mekanizasyondan yeterince faydalanılmadığı için verim çok düşüktür. Muş Ovası'nda yetiştirilen ürünler şekerpancarı, nohut ve tahıllarla sınırlıdır. Buna ek olarak küçük ölçekte tütün üretimi de yapılmaktadır (Muş İl Gıda Tarım ve Hayvancılık Müdürlüğü, 2015). İl, büyük bir tarım ve hayvancılık kapasitesine sahip olmasına rağmen ifade edilen nedenlerden dolayı bu değerlerini şu ana kadar ekonomik bir çıktıya dönüştürememiştir.

Geçmişte ilin bu tarım ve hayvancılık potansiyelini değerlendirmek amacıyla, 1970'li yılların sonunda sanayi alanında devlet tarafindan önemli girişimler başlatılmıştır. $\mathrm{Bu}$ girişimler; ilin hayvancılık potansiyelini değerlendirmek amacıyla Muş Et ve Balık Kombinası, meyan kökü hammaddesini değerlendirmek amacıyla Muș Meyan Kökü Fabrikası ve tarımsal ürünleri değerlendirmek amacıyla da Muş Gıda Ürünleri Sanayii kuruluşlarının planlanması şeklinde olmuştur. Ancak, yapımı planlanan bu sanayi tesisleri farklı zamanlarda, fiziki olarak yaklaşık \%80 gibi makine montaj aşamasında iken çeşitli nedenlerden dolayı bitirilmemiş ve atıl vaziyette bırakılmıştır (Asi, 2012: 43). Muş'un geçmişinde yaşanan sanayi alanındaki bu olumsuzluklar, bulunduğu bölgede aynı potansiyele sahip diğer illere göre geri kalmışlığının en önemli nedeni olarak gösterilmektedir. Çünkü bu tür büyük devlet işletmeleri geçmişte illerin gelişiminde lokomotif işlevi görmüştür. İlde bu olumsuz gelişmelere rağmen, son yıllarda devlet teşviklerinin de katkısıyla özel sektör, çoğunluğu küçük ölçekli ve az sayıda orta ölçekli sanayi işletmeleri kurmaya başlamıştır. İlde Küçük ve Orta Ölçekli İşletmeleri Geliştirme İdaresi Başkanlığı'nın (KOSGEB) 2011-2014 yılları arasında KOBİ'lere sağladığı hibe miktarı 3.714.523 TL (KOSGEB, 2015), Doğu Anadolu Kalkınma Ajansı'nın (DAKA) 2010-2014 yılları arasında KOBİ ve şahıs firmalarına sağladığı hibe miktarı 18.798.153 TL (DAKA Muş Yatırım Destek Ofisis, 2015), Doğu Anadolu Projesi'nin (DAP) 2013-2015 yılları arasında ilde desteklediği proje miktarı 11.415.500 TL olmuştur (DAP, 2015). Tarım ve Kirsal Kalkınmayı Destekleme Kurumu'nun (TKDK) 20122015 yılları arasında şahıslara sağladığı kırsal kalkınma hibe destek miktarı kabul edilen projeler bittiğinde 85.452.895 TL olacaktır (TKDK, 2015). Bu veriler kamunun ilde son yıllarda küçük ve orta ölçekli işletmelerin oluşumundaki önemli katkısını açıkça göstermektedir. Bu işletmelerin ve gelecekte kurulacakların ayakta kalabilmesi ve sürdürülebilir bir sanayi oluşumu için, stratejik bazı hamlelere ve ile özgü yapısal yeni bir kurguya gereksinim vardır. Devlet teşviklerinin etkin kullanımı ve doğru yapısal bir kurgu inşası için ilgili kamu kuruluşlarının katkılarına ek olarak Muş Alparslan Üniversitesi’nin (MŞÜ), ildeki odalar ve sivil toplum kuruluşlarının katılımıyla Muş Sürdürülebilir Kalkınma Platformu'nun (MSKP) oluşturulması yerinde olacaktır. Bu platform öncülüğünde, Ankara merkezdeki ilgili aktörlerle uyumlu çalışılarak il için etkin bir ekonomik yapılanma ve sanayileşme stratejisi belirlenebilir. Ayrıca üretilen ürünlerin yüksek bir fiyata satılabilmesi, yani katma değer oluşturabilmesi için marka şehir bağlamında Muş’a özgü bir tanıtım ve pazarlama stratejisi geliştirilmelidir. Etkin bir tanıtım ve pazarlama stratejisiyle, üretilen doğal ürünler için pazarlar bulabilmek çok önemlidir. Çünkü bugün ildeki işletmelerin en büyük sorunu ürettikleri malları satabilecekleri pazarlar bulamamalarıdır. Buna ek olarak işletmeler, ürünlerini satabilecekleri pazarlar bulunabilmesi için mali ve yapısal çeşitli stratejik teşvik unsurlarıyla desteklenmelidir. Ürettiklerini satarak ayakta kalan ve gelişerek büyüyen işletmeler katma değer üretmeye başlayacak ve bu da ilin sürdürülebilir ekonomik gelişimini sağlayacaktır.

\section{Muş Ekonomisi ve Sanayiinin Geçmişten Günümüze Gelişimi}

Muş ili genelinde halen 92 anonim şirket, 1097 limitet şirket, 17 kolektif şirket mevcuttur. Ayrıca 62 adet Tarımsal Kalkınma Kooperatifi, 1 adet Pancar Ekicileri Kooperatifi, 4 adet Esnaf Kefalet Kooperatifi, 3 Tüketim Kooperatifi, 6 Küçük Sanayi Sitesi Kooperatifi ve 2 Tütün Kooperatifi de 
faaliyetlerde bulunmaktadır. İldeki 7 esnaf odasının toplam üye sayısı 4.374'tür. Bu firmalar içinde Sanayi Sicil Belgesi alan firmalar 127 adettir ve firmalarda istihdam edilen eleman sayısı 2862'dir. Muş Sanayi ve Ticaret Odasına kayıtlı imalatçı firma sayısı 95'tir (Muş Bilim, Sanayi ve Teknoloji Müdürlüğü, 2015; Muş İl Gıda Tarım ve Hayvancılık Müdürlüğü, 2015).

İlde faaliyet gösteren firmaların üretim alanları çimento, tarım makineleri, barit madeni işletmeciliği, tekstil, hazır giyim, mobilya, hazır beton, karma yem, unlu mamuller, süt ve süt ürünleri, şeker, sıcak asfalt, taş ve mıcırdır. Muş sanayisi ağırlıklı olarak küçük ve orta ölçekli işletmelerden meydana gelmektedir. Büyük ölçekli sanayi kuruluşları olarak şeker fabrikası ve çimento fabrikası; orta ölçekli işletme olarak barit fabrikası, tuğla fabrikası, mermer fabrikası, tekstil fabrikası ve muhtelif gıda, plastik ve metal eşya fabrikaları faaliyet göstermektedir (Sanayi Genel Müdürlüğü, 2016:1029-1043 ). İlin en büyük sanayi tesisi olan Muş Şeker Fabrikası, 1982 yılından beri faaliyettedir. Fabrikanın kapasitesi 3.600 ton/gündür. Fabrika, kampanya döneminde şeker pancarı yetersizliği ve diğer nedenlerden dolayı tam kapasiteyle çalışmamasına rağmen il ekonomisine büyük katkıda bulunmaktadır. 2014 yılında 236.000 ton pancar işlenerek 32.370 ton şeker elde edilmiştir (Türkiye Şeker Fabrikaları A.Ş., 2014: 55). 2009 yılında faaliyete giren çimento fabrikası ilin şu ana kadarki en büyük özel sektör yatırımıdır ve yıllık çimento üretim kapasitesi 924.000 tondur. Üretilen çimento Doğu Anadolu Bölgesi, Güneydoğu Anadolu Bölgesi ile komşu Ortadoğu ülkelerine ihraç edilmektedir (Yurt Çimento, 2015).

Teşvik yasasıyla desteklenen tekstil, deri, plastik, metal işleri ve mobilya gibi sektörlerde ilde son zamanlarda önemli yatırımlar gerçekleşmektedir (Muş Valiliği, 2015). Bu teşviklerle gelişen Malazgirt ilçesindeki Tarım Makineleri İhtisas Sanayi Sitesi önemli bir yere sahiptir.

İlde Muş Organize Sanayi Bölgesi, Muş Sanayi Merkezi, Malazgirt Tarım Makineleri İhtisas Sanayi Sitesi ve 5 adet küçük sanayi sitesi bulunmaktadır. $\mathrm{Bu}$ küçük sanayi sitelerinin üçü il merkezinde, diğer ikisi Bulanık ve Malazgirt ilçelerinde hizmet vermektedir. Bunun dişında Varto ilçesinde bir adet küçük sanayi sitesi bitme aşamasındadır. İlde sanayinin gelişmesine büyük katkıda bulunacak Muş Organize Sanayi Bölgesinin (MOSB) yapımına 2002 yılında başlanmış ve bölge 2008 yılında hizmete açılmıştır. 90 hektarlık alanda 54 fabrika kapasiteli olarak planlanan MOSB'nin fiziki gerçekleşmesi tamamlanmış ve şu ana kadar 35 parsel tahsis edilmiştir. Bölgede 19 parsel boş bulunmakta ve arsaların yatırımcılara tahsis edilmesinde büyük kolaylıklar sağlanmaktadır. MOSB'de 8 firma üretim yapmakta olup 5 firma üretim aşamasında, 2 firma inşaat aşamasında ve 20 firma proje aşamasındadır. Üretime geçen firmalarda yaklaşık 85 kişi çalışmaktadır (Muş OSB Müdürlüğü, 2015). Ancak OSB'nin mevcut yerini belirlemede etkili olan yereldeki siyasi aktörlerin yer seçimi belirleme döneminde çıkar elde etme odaklı hareket etmeleri nedeniyle yerleşke iş dünyasından gereken rağbeti görmemiştir. Zira OSB yerleşkesi kent merkezinden $27 \mathrm{~km}$ uzaktadır. Ayrıca seçilen yer terör hedefi olma riski taşımaktadır. Bu sebeplerden ötürü tahsis edilen parsellere yatırım yapılmadığı ya da yatırım yapılan işletmelerden yeterli randıman alınamadığı için bölge şu an için tam randımanla kullanılamamaktadır. İl merkezinde İl Özel İdaresi'ne ait Muş Sanayi Merkezi'ndeki toplam 39 gayrimenkulün hepsi yatırımcılara tahsis edilmiştir. $\mathrm{Bu}$ merkezdeki ağırlıklı sektörler tekstil, mobilya, gıda, metal ve plastiktir (Muş Valiliğii, 2015).

\section{3. İldeki Sektörlerin Envanteri}

Muş ilinde şu anda öne çıkan sektörleri gıda, tarım alet ve makineleri, tekstil, madencilik, plastik ve inşaat yap1 malzemeleri oluşturmaktadır. Bu sektörler aşağıda genel hatlarıyla ele alınacaktır:

Gıda Sektörü: Gıda sektörü, ilde öne çıkan sektörler arasında işletme ve çalışan sayısı açısından ilk sırayı almaktadır. Muş, bir tarım ve hayvancılık şehri olduğundan gıda sektöründe hammadde ihtiyacını yerelde temin etme avantajına sahiptir. $\mathrm{Bu}$ nedenle gıda alanında faaliyet gösteren birçok firma vardır. Gıda sanayisinde ilde öne çıkan sektörler lokumşeker, un ve yem, süt ve süt ürünleri imalatıdır. İlin en büyük devlet yatırımı olan şeker fabrikası faaliyetlerine devam etmektedir. Bununla birlikte modern hayvan çiftliklerinin sayısı devlet hibe destekleriyle artmaktadır. Örneğin bu çiftliklerin 44 tanesi hâlihazırda TKDK tarafından yaklaşık $\% 65$ hibe desteğiyle kurulmuş veya kuruluş süreci devam etmekte olup 34 tanesi süt 10 tanesi ise et üretmek amaciyla desteklenmiştir (TKDK, 2015). İlde yeterli olmasa da faaliyette bulunan 7 süt işleme tesisi bulunmaktadır. Bu tesislerin toplam süt işleme kapasitesi 3.067 ton/yıldır. Bu işletmelerden dört tanesi DAKA ve TKDK hibe teşvikleriyle desteklenmiştir (DAKA Muş Yatırım Destek Ofisi, 2015; TKDK, 2015). Muş kaşarını mevsimlik olarak üreten 4 süt işleme firması mevcuttur (Muş İl Gıda Tarım ve Hayvancılık Müdürlüğü, 2015). İldeki mera sütünden imal edilen Muş kaşarı, markalaşma veya pazarlama için özel bir çaba harcanmamasına rağmen, lezzetinden dolayı İstanbul Mısır Çarşısı'nda Trakya kaşarından sonra en pahalı kaşar olarak talep görmektedir. Ancak ildeki kaşar üreticileri yurt içi talebi bile karşılayamamaktadır. Muş kaşarının Türkiye'nin en sağlıklı ve lezzetli kaşarı yapılabilecek niteliklere sahip olması, doğru pazarlama stratejisiyle ülkenin en pahalı kaşarı olup dış pazarlarda da iyi bir fiyata satılabilme potansiyeline sahip olması anlamına gelmektedir. İlde küp şeker üretimi yapan iki önemli firma vardır. Bunlar Zümrüt Şeker ve Baltat firmalarıdır. $\mathrm{Bu}$ firmalardan Zümrüt Şeker'de 46 işçi çalışmaktadır. Firma günlük 30 ton kapasiteyle faaliyettedir. Baltat ise 22 kişi çalıştırmaktadır ve günlük 20 ton üretim kapasitesine sahiptir. Bu firmalar Doğu ve Güneydoğu Anadolu'nun tüm illerine satış yapmakta olup ülkenin tümüne açılmak için tanıtım ve pazarlama desteğine ihtiyaç duymaktadırlar (Muş Ovası Gazetesi, 2010; Muş Ovası Gazetesi, 2008).

Tarım Alet ve Makineleri Sektörü: Tarım alet ve makineleri ilde öne çıkan ve gelişme potansiyeli yüksek sektörlerden biridir. Tarım alet ve makineleri üretimi Malazgirt ilçesinde Tarım Makineleri İhtisas Sanayi Sitesi'nde (TARMISS) yığılmış olup küme özelliği gösterme eğilimindedir. İlçede 10 adet üretici firma vardır. Bu fiziki kümeleme içindeki firmalar arasında patent başvurusunda bulunan, yeni ve farklı model makine üreten ve ihracat yapanlar vardır. Bu işletmelerden 5'i Malazgirt ilçesinde 1'i merkezde olmak üzere 6 tanesi DAKA'nın hibe desteklerinden yararlanmıştır (DAKA Muş Yatırım Destek Ofisi, 2015). Sektörün iç ve dış 
pazar potansiyeli, gerekli destek ve yönlendirmelerle büyük gelişme sergilenebileceğini göstermektedir.

Tekstil Sektörü: Tekstil, ucuz iş gücü, arsa tahsisi kolaylı̆̆g, devletin sağladığı sigorta primi indirimi, vergi indirimi ve özellikle Ortadoğu ve Orta Asya pazarlarına yakınlık gibi faktörlerden dolayı gelişme gösteren bir sektördür. İlde faaliyet gösteren orta ve küçük ölçekli firmalar bulunmaktadır. Buna ek olarak Muş Valiliği öncülüğünde, 2016 Eylül ayı sonunda Muş merkeze bağlı Sungu beldesinde "Tekstil Kent" adlı proje faaliyete geçirilmiştir. $\mathrm{Bu}$ proje kapsamında başlangıçta yaklaşık 2500 kişinin istihdam edilmesi öngörülmektedir (Muş'un Sesi Gazetesi, 2016). Özellikle yukarıda bahsedilen komşu ülke pazarlarına yakınlık ve ucuz işgücünden dolayı gelişme potansiyeli yüksek olan bu sektörün desteklenmesi işsizlikten kaynaklı batıya göçü azaltabilir.

Mobilya Imalatı Sektörü: Mobilya imalatı sektörü yoğun emek gerektiren bir sektördür. İlin ucuz iş gücü potansiyeli, il ve bölgenin talebi, devletin sağladığı teşvikler ve komşu ülkeler ile Orta Asya pazarlarına ihracat potansiyelinden dolayı bu sektör ilde önemli bir yatırım kalemini oluşturmaktadır. İlde mobilya üretim sektöründe küçük ve orta ölçekli birçok firma faaliyetlerini sürdürmektedirler. Bu firmalar arasında yurt dışına küçük ölçekli ihracat yapanlar da bulunmaktadır (Dünya Gazetesi, 2011). Fakat bu sektörde birçok yoğun emek sektöründe olduğu gibi yeterli kalifiye eleman bulma sıkıntısı yaşanmaktadır. Ayrıca ihracat ve katma değer oluşturan ulusal pazar için gerekli olan ISO ve CE kalite standartlarında mal üretiminin gerekliliği konusunda yeterli bilincin olmaması gibi pazarlama ve tanıtım konusunda yaşanan yetersizlikler de göze çarpmaktadır.

Madencilik Sektörü: İlde barit, çimento hammaddelerinden kalker ve kil, tuz yatakları, mermer, tuğla, kiremit, kuvarsit, alçıtaşı, jips, kraki, kireçtaşı bulunmakta ve işlenmektedir. Sözü edilen madenler dişında ilde enerji hammaddeleriyle ilgili yapılan çalışmalar sonucunda Ziyaretköy sahasında linyit oluşumları tespit edilmiştir (MTA, 2015). İlde çimento, barit, tuğla ve tuz fabrikaları da bulunmaktadır. İldeki barit yataklarının bir kısmı değerlendirilerek hammadde olarak ihraç edilmektedir (Muş Valiliği, 2015). İldeki yer altı ve yer üstü kaynaklarının birçoğunun tespitinin Ankara merkezden ve yetersiz teknoloji kullanılarak yapılmış olması ve güvenlik sorunları sebebiyle ildeki madenlerin tam olarak tespit edilemediğine inanılmaktadır. $\mathrm{Bu}$ nedenle ilin yer altı ve yer üstü kaynakları yeni teknolojiler kullanılarak tekrar tespit edilmeli ve maden envanteri güncellenmelidir.

Plastik Sektörü: İlde plastik sektörüne yönelik olarak peynir kab1 ve bidon imalat1 yapan firmalar mevcuttur. Bunlardan özellikle Muș Plastik firması plastik bidon sektöründe hem ürün kalitesi hem de ilin lojistik avantajından faydalanarak Doğu ve Güneydoğu piyasasında yer edinmiştir (Plastonline, 2013). Bu sektörde mutfak ürünleri ile günlük hayatta kullanılacak plastik ürünler imal edecek firmalara ihtiyaç vardır. İlin lojistik konum avantajı taşıması, maliyeti yüksek olan bu ürünleri burada üreten işletmelerin İstanbul ve batıdaki diğer büyük merkezlerde üretim yapan firmalarla rekabet edebilmelerine olanak sağlamaktadır.

Inşaat Sektörü: İnşaat sektörü birçok sektörü harekete geçiren ve ekonomik canlılığı sağlayan kilit sektörlerden biri olup il için oldukça önemli ve hızlı büyüyen bir sektördür. Ancak yetersiz planlama ve denetim, vizyon eksikliği vb. nedenlerden ötürü ilde çarpık kentleşme devam etmektedir. İlde 11 adet beton santrali, 12 adet taş ve micır üretim tesisi (agrega) ve 6 adet yapı denetim firması bulunmaktadır (Muş Çevre ve Şehircilik Müdürlüğü, 2015). Bölgenin deprem kuşağında yer alması ve kışların uzun ve çetin geçmesinden dolayı inşaat sektörünün daha az maliyetle daha kaliteli ürün ve hizmet vermesi önemlidir. Bu bağlamda Muş Bazaltı, Liz Taşı, Şenyayla Bazaltı ve Muş Beyazı gibi 1sı yalıtımı yüksek inşaat yapı taşı ve malzemelerini değerlendirebilecek, bunları inşaat sektörünün değişik alanlarında kullanılabilecek yapı malzemeleri haline getirebilecek işletmelerin kurulumu teşvik edilebilir (Muş Valiliği, 2015). Isı yalıtım yapı eleman ve malzemeleri, ilin bu doğal hammaddelerinden yapıldığında ilin ve bölgedeki diğer illerin ihtiyacını karşılayabileceğinden pazarı hazır bir üründür. Ayrıca inşaat sektörü özellikle niteliksiz elemanların istihdam edildiği alanlardan biri olduğundan ildeki genç işsizler için bir iş kapısıdır. Bu sektörde öne çıkan ana sorun ince işçilik yapacak kalifiye eleman eksikliğidir. Ayrıca bu sektörde yurt dışına açılmaya yönelik bir vizyona gereksinim vardir.

Enerji Sektörü: İlde kurulan Enerji ve Sulama amaçlı baraj ve Hidroelektrik Santrali (HES) işletmelerinin bir kısmı tamamlanmış bir kısmı ise inşaat aşamasındadır. İlde aktif olan Alparslan I Barajının, Malazgirt HES ve Varto HES'in yıllık toplam enerji üretimi 492.3GWh’tır. Ayrıca inşaat safhasında olan Alparslan II Barajı ve HES, Doğan HES ve Kamer HES'in inşası tamamlandığında yıllık enerji üretimi 894.66 GWh olacaktır (DSİ, 2015).

Arıcılık: Muş ilinde önemli miktarda bal üretimi gerçekleşmektedir. Bununla birlikte kamunun sağladığ desteklerle bu miktar gittikçe artmaktadır. Örneğin TKDK şu ana kadar 21 işletmeye 1.535.460.56 TL parasal destek sağlarken Gıda, Tarım ve Hayvancılık İl Müdürlüğü 20102014 yılları arasında 893.620,68 TL destek sağlamıştır (TKDK, 2015; Gıda, Tarım ve Hayvancılık İl Müdürlügüü, 2015). Muş ili bitki florasının zenginliği ve ekolojik şartlarının uygunluğundan dolayı üretilen bal kaliteli ve lezzetlidir. Ancak değişik kalitede üretilen organik ve organik olmayan bal üretimini sınıflandıracak bir birimin ve bu sınıflandırmaya bağlı etkin bir tanıtım ve pazarlama sisteminin yokluğuna ek olarak ambalajlama yetersizliğinden dolayı üreticiler baldan hak ettikleri ekonomik getiriyi elde edememektedir. Sonuç olarak organik arıcılık için uygun ekoloji ve endemik bitki florasına sahip olan ilde üretilen balın kalitesini tescilleyen bir birim meydana getirilirse il bu alanda Türkiye pazarında söz sahibi olmakla kalmaz dış pazarlara da açılabilir.

Meyvecilik: İlde meyvecilik ve bağcılık için ideal havzalar bulunmasına rağmen hâlihazırda bu konuda yerelin ihtiyacını karşılayacak üretim bile yapılamamaktadır. Hâlbuki geçmişte bağ ve bahçelerden bölge insanları geçimlerini sağlamaktaydı. $\mathrm{Bu}$ durum ilin doğru bir planlama ve stratejiyle bağcılık ve meyvecilik açısından önemli bir konuma gelebilecek potansiyeli olduğunu göstermektedir. Özellikle ile has üzüm çeşitleri, ceviz, armut ve elma gibi meyveler ve ilin gecikmeli gelen yazlarından dolayı geç turfanda olarak yetişen kiraz gibi pazar sorunu olmayan meyve çeşitleri yetiştirilerek ile ekonomik kazanç 
sağlanabilir (Muş İl Gıda Tarım ve Hayvancılık Müdürlüğü, 2015; Milliyet Gazetesi, 2016).

Turizm Sektörü: Muş, dağ-doğa turizmi, kültür turizmi ve kış turizmi potansiyelini değerlendirebilecek olan ancak yatırım ve tanıtım yetersizliklerinden dolayı turizm gelirleri olmayan bir ildir. İlin değişik bölgelerinde yer alan cami, köprü, hamam, kale ve kiliselerin restore edilip turizme kazandırılması gerekmektedir. Telli turna kuşu Türkiye'de sadece Bulanık ilçesinde yavrulamaktadır ve toy kuşunun ülke popülasyonunun üçte biri bu ilde yaşamaktadır (Muş İl Kültür ve Turizm Müdürlüğü, 2015). Bunlar için kuş gözlem alanları oluşturulmalıdır. Höyük kazıları ile diğer arkeolojik kazılardan elde edilen tarihi eserler Muş'ta müze bulunmadığı için bölge müzelerinde sergilenmektedir. Malazgirt Panorama 1071 müzesinin yapılması ve önemli tarihi eserlerin onarılmasıyla ilde yakın bir gelecekte kültür turizmi canlanabilir.

Hizmet Sektörü: Muş ilinde hizmet sektörü özellikle Muş Alparslan Üniversitesinin kurulmasıyla birlikte canlanan bir sektör olmaya başlamıştır. İlde birbiri ardına restoranlar, kafeler ve marka ürünler satan mağazalar açılmaya başlamıştır (Sırım ve Çayın, 2014: 72). Mevcut işletmeler de daha modern bir tasarımla kendilerini yenileme çabası içine girmiştir. Ancak sektördeki bu hızlı büyümeyle doğru orantılı olarak nitelikli servis elemanı sıkıntısı yaşanmaktadır.

\section{Ekonomik Potansiyel Açısından Muş İlinin SWOT Analizi}

İlin sosyo-ekonomik yapısı ve potansiyeli analiz edilmeden ilin sunacağı firsatlar görülemez ve bu firsatlar değerlendirilerek katma değer oluşturabilecek sürdürülebilir ekonomik bir gelişim üretilemez. Muş il nüfusunun büyük çoğunluğu kırsalda yaşadığı ve doğal tarım ve hayvancılık ürünlerini doğal gıda olarak pazarlayamadıkları için ilde ekonomik refah seviyesi düşüktür. Tarımda verimlilik için mekanizasyon ve teknolojinin kullanımıyla, hayvancılıkta da süt işleme ve et entegre tesisleri gibi tesislerin kurulmasıyla doğal gida sektörü, şehrin ekonomik gelişimine büyük katkı sunabilecektir.

Bir ilin ekonomisinin gelişiminde şehirlerin oluşturacağı öz sermayenin önemi yadsınamaz. Her ilin sermaye birikimi için farklı potansiyelleri vardır. İller, ekonomik gelişim stratejisi kurgularken öncelikle kendi doğal kaynaklarına yönelik bir ekonomik büyüme stratejisi izlerler. Bu sermaye birikimiyle ilde diğer sektörler gelişebilir. Çukurova Bölgesi'ndeki ekonomik gelişim bunun en güzel örneklerinden biridir. Birçok büyük sanayici sermaye birikimlerini endüstriyel bir tarım bitkisi olan pamuğu ekerek veya pazarlayarak yapmışlardır. Daha sonra elde ettikleri bu sermayeyi farklı sektörlerde değerlendirmişlerdir. Yukarıda söylenenleri kanıtlayan en güzel örneklerden biri Sabancı Holding'in gelişim hikâyesidir. Sabancı Holding, Çukurova'nın verimli, sulak ve güneşli arazilerinden faydalanılarak üretilen pamuğu işleyerek, sonrasında tekstilden elde edilen finansal getirileri değerlendirerek Türkiye'de kayda değer bütün sektörlerde söz sahibi bir marka olmuştur (Eden, 2015).

Muş'un potansiyeli ise doğal tarım ve hayvancılıktır. Muş Ovası'nın yaklaşık \%90'ı tarıma uygundur (Sönmez, 2014:
31; Muş İl Gıda Tarım ve Hayvancılık Müdürlüğü, 2015). Ova, şu ana kadar konvansiyonel endüstriyel tarım yapılmamasından dolayı kimyasallarla kirlenmemiştir. $\mathrm{Bu}$ yönüyle Türkiye'nin temiz kalabilmiş ender ovalarından biridir. Bu durum ilin kalkınabilmesi için büyük bir şanstır ve Muş'un bu potansiyeli kenti şimdi ve/veya gelecekte önemli ekonomik merkezlerden biri haline getirebilecek imkânlar sunmaktadır. Çünkü dünyamızın gelecek açısından stratejik öneme sahip iki yatırım alanından biri tarım diğeri ise enerjidir. Muş Ovası bu bakımdan hem il sakinlerine hem de ülkeye büyük hizmet sunabilir. Özellikle dünyada önemi gittikçe artan organik tarım için hiçbir ek harcama ve yatırım gerektirmeksizin işlenebilecek bir ova olması il ve ülke için büyük bir nimettir.

Önceki bölümlerde geçmişten günümüze Muş ekonomisi ve sanayisi irdelenmiştir. Şimdi Muş ilinin ekonomik gelişim açısından güçlü ve zayıf yönleri, sunduğu firsatlar ve ilin ekonomik gelişimine tehdit oluşturabilecek etmenler ayrı başlıklar altında ele alınacaktır.

\section{1. İlin Güçlü Yönleri}

Muş ilinin güçlü yönleri aşağıdaki ana başlıklarda toplanabilir:

Doğal Tarım ve Hayvancılık Potansiyeli: Türkiye'nin en büyük ovalarından biri olan Muş Ovası ile Bulanık Ovası, Malazgirt Ovası ve Liz Ovası ili hayvancılık ve tarıma dayalı sektörler açısından cazip ve güçlü kılmaktadır (Muş İl Gıda Tarım ve Hayvancılık Müdürlüğü, 2015). Ayrıca doğal meraların bolluğundan dolayı hem büyük bir hayvan stoku vardır hem de hayvanlar doğal beslendiğinden hayvansal ürünler doğal ve lezzetlidir. Bu da özellikle dünyada ve ülkemizde gittikçe artan sağlıklı beslenme talebine hitap edebilecek bir potansiyel sunmaktadır (Hallam, 2003: 180181). Mera ürünleri kapalı alanlarda beslenen hayvanlardan elde edilen organik gıdadan daha sağlıklıdır. Bu durum mera süt ve et ve organik tarımsal ürünler için ilde yatırım yapacak firmalar için büyük ve karlı bir yatırım imkânı sunmaktadır.

Ayrıca Muş ilinin ekolojik yapısı, doğal meyve ve bitki florasının zenginliği organik arıcılık için oldukça uygun koşullar sağlamaktadır. Muş balı bölgede ünlü bir bal olmasına rağmen tanıtım yetersizliğinden dolayı Türkiye'de yeterince bilinmemektedir. Buna ek olarak ilde katma değeri yüksek organik endüstriyel tarımsal ürünler ekilebilir. Bunun için ilin toprak yapısı ve iklimine uygun tarımsal ürünlerin tespiti ve ilde yetiştirilebilmesi için iç ve dış paydaşların bilimsel araştırma ve saha çalışmalarına gereksinim vardir.

Lojistik Konum Avantajı: Muş Doğu ve Güneydoğu Anadolu'nun kavşak noktasında yer almaktadır. Doğu ve Güneydoğu Anadolu Bölgesi'nin 6 iliyle sınır komşusudur. Komşu illerden Bitlis ve Bingöl'e 1 saat, Erzurum, Diyarbakır ve Batman'a 2 saat, Ağrı iline ise 3,5 saat uzaklıktadır. Sınır komşusu olmamasına rağmen Van ve Elazığ illerine karayoluyla yaklaşık 3 saat uzaklıktadır (Karayolları Genel Müdürlüğü, 2017). Muş'un çevre illerle karayolu ulaşımı genelde ovanın bitimiyle başlayan dağların yamaçlarından dolanılarak yapılmaktadır. Dolayısıyla bu 
ulaşım yollarının birçok yerinde tüneller yapılarak ve dağlar yarılarak mesafenin büyük ölçüde kısaltılması imkânı vardır. Hatta bu ulaşım yollarından bazılarında mesafenin yarı yarıya düşürülebilme potansiyeli ilin lojistik konumunu daha da güçlendirmektedir. Bölgenin önemli illerine olan hâlihazırdaki karayolu yakınlığı ve mesafelerin daha da kısaltılma potansiyeli, ili İstanbul gibi uzak merkezlerde üretim yapan firmalar için potansiyel bir lojistik dağıtım merkezi yapmaktadır. Lojistik depolama kullanım amacına bağlı olarak genelde klasik depo, dağıtım merkezi, toplama merkezi, aktarma merkezi ve sipariş işleme merkezi şeklinde beşe ayrılmaktadır. Bunlardan dağıtım merkezi; üretici veya tedarikçilerin müşteri pazarına yakın noktalarda konuşlandırdıkları ve büyük hacimli malları bir depoda toplayarak hızlı ürün teslimatı sağladıkları merkez olarak tanımlanmaktadır (Tanyaş ve Arıkan, 2013: 22). Bu tanım dikkate alındığında Muş'un bölge için ideal bir dağıtım merkezi olabileceği açıkça görülmektedir.

Ayrıca ilin İran'la bağlantılı demiryolu ağı vardır. Haftanın her günü Türk Hava Yolları (THY) Ankara, İstanbul ve belirli günler direkt Bursa; Pegasus Havayolları ise İstanbul ve İzmir seferleriyle havayolu ulaşımı sağlanmaktadır. Ayrıca ilin yukarıda bahsedildiği gibi bölgedeki önemli illere yakınlığı ve komşu ülkelerden Irak, İran ve Suriye'ye olan yakınlığı burada kurulacak sanayi tesislerine lojistik avantaj sağlayacaktır.

Genç ve Ucuz İş̧ilik Avantajı: Muş Türkiye'nin en genç nüfusa sahip illerinden biridir (TÜİK ADNK, 2015). Bu durum kurulacak işletmelere ucuz ve dinamik bir iş gücü avantajı sunmaktadır. İşletmeler bu sayede maliyetlerini düşürme olanağı bularak pazarda rakiplerine karşı rekabet üstünlüğü sağlayabilir.

Madencilik ve Yer Altı Kaynakları Avantajı: İlde çimento hammaddesi olarak kullanılan büyük miktarda kalker ve kil rezervi, tuz yatakları, mermer, iyi-orta kalitede tuğla-kiremit hammaddesi, büyük miktarda barit rezervi, kuvarsit, alçıtaşı, jips, kraki, kireçtaşı ve linyit rezervleri bulunmaktadır (MTA, 2015). İlin mevcut rezervleri ile henüz tespit edilmemiş maden rezervleri bu alanlarda işletmeler kurulmasına imkân sağlayacaktır.

Muş Alparslan Üniversitesi'nin (MŞÜ) Kurulması ve Gelişim Potansiyeli: MŞÜ, 10 yıllık geçmişi olmasına rağmen kampüs yapılanması için yapılan harcamalar, istihdam edilen personel ve sayıları yıllar geçtikçe artan öğrenciler ile şehrin ekonomisine katkı sağlamakta; ayrıca eğitim yoluyla direkt veya dolaylı olarak Muş'un sosyoekonomik gelişiminde önemli rol oynamaktadır. Örneğin MŞÜ' nün 2009 yılında öğrenci sayısı 1570 ve çalışan sayısı ise 252 iken 2017 yılında öğrenci sayısının, on bine, personel sayısının da bine yaklaşması bu katkının yıllar geçtikçe arttığını ispat etmektedir (Sırım ve Çayın, 2014; Günaydın Muş Gazetesi, 2015). Ayrıca Eylül 2017'de açılan MŞÜ Uygulamalı Bilimler Fakültesinin, ziraat ve veterinerlik alanlarına yönelik eğitim ve araştırma çalışmaları yaparak Muş'un tarım ve hayvancılıkta hak ettiği konuma kavuşması için katkılar sunması beklenmektedir (Milliyet Gazetesi,
2017). Tüm bu ilerlemelere rağmen Muş'un sosyoekonomik gelişmişlik açısından son sıralarda yer alması MŞÜ'ye ve ildeki tüm kamu kurum ve kuruluşlarına daha özverili çalışma sorumluluğu yüklemektedir. Ancak küçük illerde kurulan yeni üniversitelerin genelinde olduğu gibi yeterince kurumsallaşamama ve nitelikli personel istihdamını sağlayabilecek cazibe yoksunluğu gibi sorunlar MŞÜ'nün Muşa katkısını sınırlandırmaktadır. Ayrıca MŞÜ yerleşkesi iki köy arasında sıkışmış ve dağ yamacının alüvyon zemini üzerindeki alanda konumlandırılmıştır. Bu durum deprem kuşağında yer alan bir il için problem teşkil etmektedir. Buna ek olarak üniversite kampüsü ile şehir merkezi arasında askeri alanların yer alması, Muş gibi küçük bir ilde kampüs yerleşkesinin ilin şehir meydanından yaklaşık $13 \mathrm{~km}$ uzak oluşu ve şehrin doğal gelişim yönünde olmaması üniversitenin ille bütünleşmesini engelleyen hususlardır. Bütün bu olumsuzluklar yer seçimi konusunda yanlış bir tercih yapıldığını göstermektedir. Bu bağlamda kampüs alanı belirlenirken dönemin yönetici kadrolarının bu konuda pek hassas davranmadıkları, gerekli olan ön araştırma ve incelemelerin yeterince yapılmadığ1 ve istişare mekanizmalarının pek sağlıklı işletilmediği sonucuna varmak pek de zor olmamaktadır. İşin üzüntü veren tarafı ise bu olumsuzlukların hiçbir surette giderilemeyecek olmasıdır.

\section{2. İlin Zayıf Yönleri}

İlin ekonomik gelişimine negatif etkisi olabilecek bazı unsurlar şunlardır:

Kalifiye Eleman Bulma Sorunu: İlin yatırımcı açısından en zayıf yönlerinden biri, bulunduğu bölgenin diğer illerinde de görülen yetersiz kalifiye ara elaman sorunudur. $\mathrm{Bu}$ durum profesyonel yönetici eksikliğinden başlayarak en alt seviyelere kadar birçok iş alanında kendini güçlü bir şekilde hissettirmektedir (Arslan, 2017a: 66-67). Az sayıdaki kalifiye eleman da çoğunlukla ildeki iş imkânlarının kısıtlı olması veya yetersiz ücretten dolayı batıdaki büyük illere göç etmektedir. Muş ili Türkiye'de doğum oranının en yüksek olduğu illerden biri olmasına karşın yoğun göçten dolay1 il nüfusu sürekli azalmaktadır. Örneğin 2013'te il nüfusu 412.553 iken yüksek doğum oranına rağmen nüfus 2015 ' te 408.728 'e düşmüştür (TÜİK ADNK, 2015).

Sermaye Yetersizliği: Yatırım ve işletme sermayesi yetersizliği il için bir diğer önemli bir sorundur. Sermaye göçü il genelinde orta ve büyük ölçekte işletmelerin kurulmasının önünde büyük bir engel teşkil etmektedir. Bölgede yatırım yapma gücüne sahip işadamlarının, terör sorunu ve ilin küçük hacimli ekonomisinden dolayı mevcut sermaye birikimlerini batıdaki büyük illerde değerlendirmeleri sermayenin ilden gitmesinin önemli nedenleri arasında gösterilebilir. Yetersiz sermayeye çare olabilecek ortak iş yapma kültürünün bölgenin birçok ilinde olduğu gibi burada da çok az olması diğer önemli bir sorun olarak kendini göstermektedir (Arslan, 2017a: 67). Bu nedenle birçok firma yeterli kurulum ve işletme sermayesi olmadan işe girişmekte ve bunun sonucunda başarısız olmaktadır. Yeterli işletim sermayesi, iyi bir fikre dayanan ve bu nedenle başarılı olabilecek firmaların başlangıçta 
ayakta kalıp kâra geçebilmeleri açısından çok kritik bir unsurdur. İşletme sermayesindeki yetersizlik ürün kalitesini kötü etkilemekle kalmaz birçok işletmenin gelir ve giderinin eşitlenerek kara geçmesini simgeleyen başa baş noktasına erişmek için gerekli zaman zarfındaki işletme harcamalarını karşılayamayarak iflas etmelerine neden olmaktadır.

Kurum ve Kuruluşlar Arası İletişim ve Koordinasyon Zayıflı̆̆l: Üniversite-sanayi ve kamu işbirliğinin zayıflı̆̆g, güçlü Sivil Toplum Kuruluşlarının (STK'ların) olmayışı, aile şirketlerinin mikro, küçük veya orta ölçek boyutunda kalmaları, kurumsallaşamamaları ve modern üretim tekniklerini yeterince kullanamamaları önemli sorunlardır. Tüm bunlar, Ar-Ge'ye dayanan ve farkındalık oluşturabilecek katma değeri olan ürünlerin ortaya çıkmasını engellemektedir. Bunun sonucunda markalaşabilecek firmalar oluşamamaktadır.

Ara Malların Uzak Mesafelerden Temini: Bölge sanayisinin gelişmemesinden dolayı işletmelerin ara sanayi mallarını Muş içinden veya yakın illerden temin edememeleri büyük bir sorundur. Ara malların uzak illerden temini ürün maliyetlerinin yükselmesine neden olmaktadır. Örneğin tarım makineleri işletmeleri ve küçük ölçekli imalat atölyeleri ilde bir dökümhane olmadığı için ihtiyaç duydukları parçaları uzak illerin dökümhanelerinde yaptırmakta, bu da üretim maliyetinin yükselmesine neden olmaktadir.

Aşiretçilik (Klancılık): Muş ilindeki aşiretçilik yapısındaki bazı değişiklikler, ağalık otoritesini büyük ölçüde aşındırmasına rağmen bir klana bağlılık belirleyici bir aidiyet olmaya devam ettiğinden aşiretçilik halen ilde seçilen yönetim erkini belirleyici ana güç olmaya devam etmektedir. Milletvekili ve yerel yönetici seçiminin yanı sıra sivil toplum kuruluşlarının yetkililerinin seçiminde de en etkin unsur olarak kendini göstermektedir (CHP Doğu ve Güneydoğu Komisyonu Raporu, 1999; Ateş Durç, 2009: 34-37; Ökten, 2010: 208). $\mathrm{Bu}$ durum ilin gelişiminde oldukça etkili olabilecek yöneticilerin daha nitelikli kişiler arasından seçilmesini engellemektedir. Muş'ta yerleşik şehirleşmiş bir kitlenin de "Muş'un Yerlileri" adı altında bu yapıya karşı çıkmaları klancılığı azaltmadığı gibi "Muş’un Yerlileri" adı altında başka bir klanı doğurmuştur. $\mathrm{Bu}$ da bu sorunu giderecek konum ve kapasitedeki kişilerin sorunun bir parçası olmasına yol açmıştır. Tüm bunlara ek olarak aşiretçilik, üretim için toplumun tüm kesimleriyle işbirliği, işbölümü ve dolayısıyla sermaye birlikteliğinin önüne geçmektedir.

Ile Ait Verilerin Nicelik ve Nitelik Bakımından Yetersiz Olması: İle ait güncel verilerin nicelik ve nitelik bakımından yetersiz olması, derli toplu olarak bir yerde bulunamaması ve bazen de farklı kaynakların birbirileriyle çelişecek veri ve bilgiler içermesi yatırımcılar için büyük bir sorundur. Çünkü verilerin doğru olmayışı ve/veya doğru verilere erişimin zorluğu girişimcilerin yanlış karar vermesine ve planlar yapmasına neden olmaktadır.
Kaynakları Klsıtlı Yerel Yönetimler: Bölgedeki birçok ilde olduğu gibi Muş ilinde de yerel yönetimlerin ekonomik gelirlerinin azlığı ve kurumsal yetersizlik, yerel yönetimlerin illerin temel sorunlarını çözmede bile zorlanmalarına neden olmaktadır. $\mathrm{Bu}$ durum yerel yönetimlerin illerin ekonomilerini ve sanayilerini canlandırabilecek gerekli altyapı çalışmalarını yapabilecek konumda olmamalarını doğurmanın yanı sıra bunların kentlerin ekonomik gelişimlerini teşvik etmek konusuna ilgisiz kalabilmelerine sebep olmaktadır. Sanayinin altyapı yetersizlikleri ise girișimciler için ekstra maliyet ve zaman kaybına neden olmaktadır. $\mathrm{Bu}$ sorun ancak sektörel kümelemenin gerçekleşeceği fiziki altyapı çalışmalarının merkezi otorite tarafından desteklenmesiyle çözülebilir.

Özel Sektörde Yetersiz Ücret, Kamuda Yetersiz ve Tecrübesiz Uzman Sayısi: Özel sektörde yetersiz ücret politikaları nedeniyle var olan az sayıdaki kalifiye eleman da daha iyi ücret için ilden göç etmektedir. Kamu kurumlarında eleman sirkülasyonunun tayin istemelerle doğudan batı illerine doğru olması Muş ilinde de yaşanılan bir olgudur (Çaha ve Tutar, 2013: 18). Başka illere atanan tecrübeli elemanların yerine yeterli sayıda eleman bulunamaması ve/veya işe yeni başlayan ve yeterince deneyimli olmayan elemanların atanması kamu kurumlarında hizmet kalitesini düşürdüğü gibi işlerin zamanında yapılmamasına neden olmaktadır. Öte yandan il sivil toplum kuruluşlarının yeterince örgütlü olmayışı; yöneticilerinin yetkinlik sorunu, kamuda usulsüzlükleri ve keyfi uygulamaları, verimliliği gayrı resmi denetlemede aktif rol oynaması gereken bu kurumları pasif bir gözlemci konumuna ittiğinden kamuda hizmet verimi batıdaki illere göre düşük seviyededir (Arslan, 2017a:61-62).

Tarım ve Hayvancılıkta Bilim ve Teknolojiden Yeterince Yararlanmama: Tarım ve hayvancilıkta teknolojiden yeterince faydalanılmaması, organize olunmaması, hayvan sağlığının önemsenmemesi ve hayvansal ürünlerin yeterince hijyenik olmaması bu alanlarda yaşanan önemli sorunlar olarak gösterilebilir. Bu sorunlar doğal gıda üretimi verimini düşürmekle kalmamakta aynı zamanda kalitesini de olumsuz yönde etkilemektedir.

Girişimci Profilinin Yetkinlik Sorunu: İldeki girişimci profilinin yönetim konusundaki yetersizliği, pazarlama yetkinliği konusundaki eksiklikleri, kalite ve standardizasyon konusundaki bilinç eksikliği hem işletmelerin gelişiminin hem de ilde sürdürülebilir bir kalkınmanın önünde engel teşkil etmektedir. Ayrıca girişimciler yatırımlarını yaparken hep kamudan destek beklemek gibi yaygın bir yanılgı içindedirler. $\mathrm{Bu}$ yüzden bölgedeki girişimciler sorunlar karşısında çözümler üretmek yerine beklenti içine girmektedir ki bu durum onların yeni ve inovatif fikirlerle pazarda yer alma yetilerinin gelişmesine engel olmaktadır (Arslan, 2017a: 66-67).

Inovasyon ve Ar-Ge Bilinç Eksikliği ve Kamu Desteklerinin Etkin Kullanılmaması: İl ekonomisi ve sanayisinin gelişip büyümesinde inovasyon ve Ar-Ge'nin önemi henüz tam olarak anlaşılmamıştır (Arslan, 2017a: 67-71). Kamusal 
desteklemeler de doğru strateji ve planlama yetersizliğinden dolayı oluşturması gerekenin çok altında bir katma değer oluşturmaktadır.

\section{3. İlin Yatırımcı İçin Sunduğu Fırsatlar}

İlin gelişimine yönelik bazı fırsatlar aşağıda verilmiştir:

Doğal Gıda Potansiyeli: İlin büyük çaplı mera hayvan stoku ve kimyasallarla kirlenmeyen ovalarının varlığı iç piyasa ve dış pazarda gittikçe artan doğal gıda talebi açısından büyük bir potansiyel sunmaktadır. Ancak burada doğru bir stratejik planlama gerekmektedir. İlde bu stratejilerin oluşumuna katkıda bulunabilecek kurumların brifinglerinde ve Ankara'nın bölgenin kalkınması için hazırlanan planlarında doğal gida potansiyelinin il gelişimindeki hayati yönünün tam anlamıyla idrak edilememiş olduğu yahut sıradan bir sektör olarak görüldüğü göze çarpmaktadır. Bu potansiyeli hakkıyla değerlendirebilmek için ilin gelişimi konusunda yetki ve imkân sahibi tüm kamu kurum ve kuruluşlarının bir araya gelip bütünsel yaklaşıma dayalı stratejik bir kurgu çerçevesinde hareket etmesi gerekmektedir.

Devlet Teşviklerinin Sunduğu Avantajlar: Muş ili devlet teşviklerinde en avantajlı bölge olan 6 . bölgede yer almaktadır. İstihdama katkı sağlayacak firmalara verilen vergi teşvikleri, belli bir süre için işçi ücret ve sigorta primlerinin karşılanması, işçi sigorta primlerinin bir süreliğine ödenmesi veya işçi sigorta primlerinde sağlanan indirimler yatırımcıya işçi maliyetlerini düşürme olanağı sağlayarak ili cazip kılmaktadır. KOSGEB'in ile sağladığı hibe oranının yüksekliği ve sıfır faizli destekler küçük ve orta çaplı işletmeler için cazip yatırım imkânları sunmaktadır. Ayrıca TUBİTAK, çeşitli bakanlıklar, KOSGEB, DAKA vb. kurumlar tarafindan sağlanan ulusal destekler ve $\mathrm{AB}$ hibe fonları; BM, Dünya Bankası vb. uluslararası fonlardan hibe, sıfır faizli veya çok düşük faizli parasal kaynak temini sağlanabilmesi hayati öneme sahip birçok projenin gerçekleştirilmesini mümkün kılmaktadır.

Yatırım Tesisi Arazi Varlı̆̆ı Avantajı: Muş Organize Sanayi Bölgesi, Muş Sanayi Merkezi, Malazgirt Tarım Makineleri İhtisas Sanayi Merkezi ve küçük sanayi sitelerinin varlığının yanı sıra yatırım yeri tahsisinde ilde sağlanan diğer kolaylıklar önemli sanayi atılımları için büyük imkânlar sunmaktadir.

Muş Alparslan Üniversitesi'nin Giderek Büyümesi: MŞÜ'nün, halen eğitim gören yaklaşık 10 bin öğrencisi, üniversite kuruluşu tamamlandığında eğitim göreceği öngörülen 20 bin öğrencisi ve bunları eğitecek akademik kadrosuyla Muş'a sağlayacağı ekonomik, sosyal ve kültürel katkıların ilin ekonomik gelişiminde potansiyel dinamikleri hayata geçireceği muhakkaktır (Günaydın Muş Gazetesi, 2015). Buna ilaveten ilin kalifiye eleman ihtiyacını giderebilme, kamu-üniversite-sanayi işbirliği oluşturabilme, Ar-Ge ekosisteminin gelişimine katkı ve SAN-TEZ gibi proje fikirlerine destek sağlayabilme kapasitesiyle MŞÜ, il sanayisine katkıda bulunabilecek konuma her geçen gün daha fazla yaklaşmaktadır. Ayrıca MŞÜ, Muş Sürdürülebilir
Kalkınma Platformu'nun önemli bir üyesi olarak Muş iline ait doğru bir ekonomi ve sanayileşme kurgusu oluşturma çalışmalarında bilimsel vizyonunu ve metodolojik yaklaşımını diğer kurum ve kuruluşların hayatın içinden gelen pratik bakış açısıyla birleştirebilir. Böylece ilde uygulanabilir ve sürdürülebilir bir ekonomik gelişimin gerçekleşmesi için doğru kurgunun oluşumu sağlanabilir.

Batıdaki Büyük Merkezlerde Yaşayan Muşlu Zengin Işsadamları: Muş ilinin ekonomik potansiyelinin küçüklüğü, aşiretçiliğin negatif etkileri ve 90'lı y1llardan itibaren özellikle ilçelerde artan terör olaylarından dolayı il dışına sermaye kaçışı olmuştur. Son zamanlarda MŞÜ'nün kurulması ve devlet teşviklerinin etkisiyle il ekonomik büyüme eğilimi göstermiş, dolaysıyla dışarıdan sermaye çekebilme potansiyeli oluşmaya başlamıştır. Ancak il, terörün etkin olduğu bölge sınırları içinde olduğundan diş yatırımcıları burada işletme kurmaya ikna etmekte hala zorlanılmaktadır. İl dışından sermaye sağlamanın en etkin yollarından biri, batıdaki büyük illerde yaşayan girişimci zengin Muşlulara yönelmek olabilir. Daha önce Muş’tan göç eden bilinen zengin Muşlularla direkt bağlantıya geçilerek veya Muşluların İstanbul ve Bursa gibi birçok büyük kentte oluşturdukları Muş kültürünü tanıtma ve yaşatma dernekleriyle bağlantıya geçilerek yatırım kapasitesine sahip kişilerin hemşerilik, gönül bağı ve maddi teşvikler aracılığıyla ilde yatırım yapmaları sağlanabilir.

\section{4. İlin Gelişimine Olası Tehditler}

İlin gelişimi için tehdit oluşturabilecek bazı unsurlar aşağıda verilmiştir:

Planl,, Özgün ve Bütünsel Bir Sanayileşme Stratejisi İlenmemesi: Kentin ekonomik gelişimine ve sanayileşmesine yönelik en büyük tehdit, Muş’ta ekonominin ve sanayinin nasıl gelişip büyümesi gerektiğine dair bir strateji geliştirmeden rastgele hareket edilmesi veya bütünsel olmayan faaliyetler içine girilmesidir. Bu durum devlet teşviklerinin etkin biçimde kullanılamamasına, kaynakların israf edilmesine ve zaman kaybına neden olmakla birlikte ildeki girişimcilik hevesinin kırılmasına da yol açmaktadır. Bu nedenle Muş Sürdürülebilir Kalkınma Platformu'nun çalıştayları ve Ankara'daki merkezi otoritenin ilgili kurumlarının katkıları sonucunda tespit edilen strateji bağlamında bütünsel bir ekonomik atılım ve sanayileşme harekâtı kurgulanmalıdır. Ekonomik değer üretme ve sanayileşme ilin güçlü yönü olan doğal tarım ve hayvancılık sektörüne dayanmalıdır. Buradaki doğal üründen kastedilen mera ve organik gıda ürünleridir. Doğal olmayan gıda pazarında yerleşik markaların egemenliğinden dolayı bu piyasada yeni bir aktör olarak mal satabilme rakiplerden çok daha ucuza satmayı zorunlu kılmaktadır. Bu yaklaşım ilin daha önce değinilen iklim özelliklerinden dolayı uygun bir tarım ve hayvancılık politikası olmadığı gibi sürdürülebilir tarım ve doğal gıdanın daha fazla katma değer üretme potansiyelini de değerlendirmemek anlamına gelir. Bu yüzden Muş doğasına uygun olarak konvansiyonel gıdaya göre göreceli olarak daha az üretilebilen ve birim piyasa değeri yüksek doğal tarımsal ve hayvansal ürünler 
üreterek bunları taze, yarı işlenmiş veya tam işlenmiş bir şekilde marka şehir bağlamında pazarlayarak ekonomik refah artırabilir.

Gerçeği Yansitmayan Resmi Verilere Göre Karar Verme: Kayıt dışı üretim ve ekonomik gösterge verilerinin bölgenin birçok ilinde olduğu gibi Muş’ta da yaygın olması ciddi bir sorundur (Arslan, 2017a: 56). İlin resmi ekonomik kazanç ve istihdam verileri gerçek değerlerden çok daha düşüktür ve resmi verilere göre değerlendirme ve analiz yapılması yanlış çıkarımlara, karar verici ve planlayıcıların yanlış adım atmasina neden olacaktır (Arslan, 2017b: 846). Bu sorunu giderme maksadiyla sahada yapilacak gayri resmi ve bilimsel çalışmalar ile resmi rakamlar ve gerçek değerler arasındaki fark belirlenebilir ve bu farka göre genel bir doğrultma katsayısı tespit edilebilir. İldeki resmi veriler bu doğrultma katsayısı kullanılarak yeniden hesaplanırsa gerçeğe daha yakın değerler elde edilmiş olacaktır. Özellikle konumuz açısından önem arz eden tarım ve hayvancılık konusunda il bazında yeni bir reel envanter çalışması yapılmalıdır. $\mathrm{Bu}$ gerçeğe yakın veriler il ekonomisinin gelişmesinde daha sağlıklı ve doğru kararlar alınmasına olanak sağlayacaktır.

Terör Sorunu: Muş nüfus oranına göre şahsa ve mala karşı işlenen suçlar bağlamında Türkiye'de en az suçun işlendiği illerden biridir (Etikan ve Erkorkmaz, 2012: 1295-1306). Ayrıca Muş'un merkez bölgesi terör sorunundan fazla etkilenmese de bazı ilçe ve çevre illerin teröre maruz kalması ve bölgenin bu konudaki kötü imajından dolayı devletin sağladığı ciddi birçok teşvike rağmen, dişarıdan sermaye sağlamakta zorlanılmaktadır. Buna ilaveten ildeki güçlü sermaye sahipleri tedirgin oldukları için sermayelerini daha güvenli bölgelere yönlendirmektedirler. Terör sorunu, kente dışarıdan sermaye girişini engellemekte ve dışarıya sermaye kaçışına neden olmaktadır. Bu durumun yanı sıra terör sorunu, kamudaki erken tayinler ile kurumlarda yeterli deneyimli eleman bulunmayışının nedenlerinden biri olarak da kendini göstermektedir (Muş Valiliği, 2015; Arslan, 2017a: 72).

İlin Birinci Derece Deprem Kuşă̆ında Yer Alması: Muş ili birinci derece deprem kuşağında yer alan bir ildir. Bu yüzden işletmeler kullanacakları binaları depreme dayanıklı biçimde yaptırmak, eski binaları ise depreme dayanıklı hale getirmek zorundadırlar. $\mathrm{Bu}$ durum işletmeciye ekstra maliyet yükleyecektir (AFAD, 2017; Dölek, 2014: 184).

Kış Mevsiminin Uzun ve Çetin Geçmesi: Bölgede kışların uzun ve çetin olması işletmeler için önemli bir sorundur. Bu durum kurulacak işletmelere hem kuruluş aşamasında hem de işletme aşamasında ek mali yük getirmektedir. Tüm bunlar kuruluş ve işletme sermayesi yetersizliği yaşayan il için ek yük anlamına gelmektedir. (Sensoy vd., 2016).

\subsection{SWOT Çıktılarının Analizi}

Buraya kadar ilin gelişim ve sanayileşme portresi çıkarılmaya çalışıldı. Bunun için geçmişten günümüze ilin gelişim serüveniyle beraber SWOT analizi yapılarak ilin kendi dinamiklerinden kaynaklanan güçlü ve zayıf yönleri ve ile dış etkenleri ifade eden firsat ve tehditler belirlenmeye çalışıldı. Bunlar yapılırken ilgili başlıklar altında her bir etmenin şehrin ekonomik gelişimine pozitif ve negatif etkileri irdelenmiş; firsatlardan gerektiği gibi yararlanmak ve negatif etkilerini bertaraf etmek veya azaltmak için nelerin yapılması gerektiği konularında görüşler ortaya konulmuştur. Burada yapılan araştırma ve analizlerden il için katma değer oluşturabilecek sektörün doğal tarım ve hayvancılık sektörü olması gerektiği sonucu ortaya çıkmıştır.

Şimdi ise doğal tarım ve hayvancılığa dayalı ekonomik büyümenin sürdürülebilir olması ve katma değer oluşturabilmesi için Muş Ovasından ve hayvancılıktan optimum seviyede faydalanabilmek için halihazırda devam eden çalışmalar ve yapılması gereken faaliyetler ile yöresel ürünlerin markalaşması ve pazarlanması konusunda yapılabilecekler başlıkları altında gerekli kriter ve öğeler tespit edilip gerekçeleriyle birlikte ele alınacaktır.

\section{Sürdürülebilir Doğal Tarım ve Hayvancılık İçin Hâlihazırda Devam Eden Çalışmalar ve Yapılması Gereken Eylemler}

Burada organik tarımın yapılabileceği Muş Ovası'ndan maksimum seviyede verim alabilmek ve merada yetişen hayvanların doğallığına zarar vermeden hayvansal ürünlerin verimliliğini artırabilecek tedbirler ayrı başlıklar altında mercek altına alınacaktır.

5.1. Muş Ovasından Optimum Seviyede Fayda Sağlayabilmek için Hâlihazırda Devam Eden Çalışmalar ve Yapılması Gereken Faaliyetler

Muş Ovası hiçbir hastalık barındırmayan ve kimyasallarla kirlenmemiş bir ovadır. Bunun nedeni daha fazla ürün elde etmek için her türlü kimyasal kullanımının yol açacağı sorunların farkına yeterince varılmadığı veya gerektiği kadar önemsenmediği bir yaklaşımın egemen olduğu yani sürdürülebilir bir tarım politikasının öneminin yeterince anlaşılmadığı 1970-1990 yılları arasında ovanın işlenmemesinden kaynaklanmaktadır. Bu yönden Çukurova, Akdeniz ve Ege bölgelerindeki havzalarla karşılaştırıldığında kimyasallarla kirlenmemiş bir toprağa sahip şanslı bir ovadır. Fakat şu ana kadar ovanın çok az bir kısmının sulanabilir tarıma elverişli olması, ovanın yeraltı su rejiminin düzenli olmaması ve toprakların ağırlıklı bir kısmının miras paylaşımıyla küçük parsellerle bölünmesi büyük ölçekli ve verimli tarım yapmayı engelleyen faktörlerdir. Fakat uzun süredir hükümetin sürdürdüğü birçok entegre paralel proje sonucunda, Muş Ovası organik tarım için çok yakın gelecekte cazip hale gelecektir. Muş Ovası'nın sunacağı potansiyelden maksimum seviyede yararlanabilmek için ovayla ilgili aşağıda belirtilen sorunların giderilmesi ve devam eden alt yapı çalışmalarının tamamlanması gerekmektedir. Bu çalışmalar Alparslan II Barajı Muş Ovası Sulama Projesi, Karasu Islah Projesi, Toplulaştırma Projesi ve Murat Nehri Taşkın Koruma Projesi faaliyetlerini kapsamaktadır. Aşağıda ilin doğal tarım kapasitesinden maksimum seviyede yararlanabilmek 
için süregelen çalışmalara ve bundan sonra yapılması gereken çalışmalara maddeler halinde kısaca değinilmiştir:

(i) Tarımın en büyük altyapı sorularında birisi arazilerin küçük parsellere bölünmüş olmasıdır. Bu sorunu gidermek için toplulaştırma şarttır. Toplulaştırma ile etkin bir tarımsal politika geliştirilerek tarımsal verimlilik ve büyük çaplı tarımsal faaliyetler için altyapı oluşturulabilir. Muş Gıda, Tarım ve Hayvancılık İl Müdürlüğünün verdiği bilgilere göre toplulaştırma çalışmalarının dörtte üçü tamamlanmak üzeredir. Bu, ovada etkin ve verimli bir tarım yapılabilmesi için çabalayan ilgili kişi ve birimlerin işlerini kolaylaştırırken bir yandan da verimli organik tarım için ovanın hazır olması anlamına gelmektedir. Muş Ovası'nın 83 köy-beldesini kapsayan toplulaştırma çalışmalarına Bulanık, Malazgirt ve Liz Ovaları da eklenmelidir (Muş Gıda, Tarım ve Hayvancılık İl Müdürlüğü, 2015).

(ii) İkinci sorun sulama sorunudur. Bu sorun da Alparslan II Barajı'nın sulama kanal projeleriyle birlikte birkaç y1l içinde tam olarak devreye girmesiyle ve arazilerinin \%95'inin sulanabilecek olmasiyla giderilecektir. Bu projeyle 78.000 hektar alan, kapalı sistem basınçlı su ile sulanabilecektir (DSİ, 2015).

(iii) Üçüncü sorun ovanın yeraltı sularının yüzeye yakınlığı ve düzensizliğinden dolayı tarımsal verimi kötü etkilemesi sorunudur. Bu sorunu giderebilmek için drenaj yapılması gerekmektedir.

(iv) Karasu Nehri'nin taşkın tehdidini bertaraf etmek için Karasu Islah Çalışma Projesiyle Karasu Nehri boyunca bu çalışmalar devam etmekte olup ovanın çoğu kısmında bu islah işlemleri gerçekleştirilmektedir. $\mathrm{Bu}$ projenin bitimiyle mendereslerin kalkması sonucu Karasu Nehri'nin 119 km olan uzunluğu 64 km'ye düşecektir (DSİ, 2015).

(v) Murat Nehri Islah Çalışması ile Murat Nehri'nin Alparslan I ve II Baraj göllerinin dışında kalan kısımlarının ıslah edilmesi için yıllara yayılan bir proje çalışması yapılmaya başlanılmıştır. Bu projenin başlangıç finansmanı temin edilmiş olup proje ihale aşamasına gelmiştir (DSİ, 2015).

(vi) Tarımsal verim için tarımsal mekanizasyon ve bilimden gereği gibi yararlanabilmek için mali ve teknik destekler sağlanılmalıdır.

(vii) Özellikle Muş Ovası için tarım alanında ek mali ve teknik destekler bir master plan çerçevesinde sağlanarak ovada sürdürülebilir organik tarım yapılması sağlanabilir.

(viii) Sürdürülebilir organik tarım için ova kimyasal gübre ve ilaçlardan sakındırılmalı ve uygun olmayan toprak işleme ve sulama tekniklerinin bir arada kullanılmasının önüne geçilmelidir. Ovanın verimli ve etkin bir şekilde kullanılıp kirletilmesinin önüne geçmek için ilgili kurumlar tarafından entegre tedbirlerin alınması gerekmektedir. Ayrıca bu tedbirlerin etkin bir şekilde yürütülmesi için çiftçilerin bilinçlendirilmesi gerekmektedir.

(ix) Berce Alparslan Tarım İşletmesi daha önce Tarım İşletmeleri Genel Müdürlüğü (TİGEM) bünyesinde olan bir devlet tarım işletmesi iken Berce bu büyük tarım işletmesini Mart 2011'de 30 yillığına TİGEM'den kiralamıştır. İşletme, ülkenin en büyük işletmelerinden biri olup tarım yapılan arazi büyüklüğü açısından üçüncü, devlete ait olmayanlar içinde ise birinci konumdadır. Bu işletmede bölgeye uygun verimli tarımsal tohumlar geliştirmeyle ilgili yoğun çalışmalar yapılmaktadır. Hatta Berce Alparslan Tarım İşletmesi yetkililerinin iddialarına göre özellikle tohumluk üretiminde Türkiye'de önemli üretim alanlarından biri haline gelmişlerdir (Berce Alparslan Tarım İşletmesi, 2017a). Burada geliştirilebilecek verimli organik tarımsal tohumlar ilin çiftçilerinin topraklarından gerekli verimi almasına büyük bir katkı sunacaktır.

\subsection{Muş Hayvancılı̆̆ı̆ıdan Gereği Gibi Yararlanabilmek İçin Yapılabilecekler}

Muş'ta doğal otlak meraların bolluğundan dolayı hayvanlar doğal beslenmekte bunun sonucunda hayvansal ürünler doğal ve lezzetli olmaktadır. Ayrıca Muş bölgesinin sütünün kuru madde oranının yüksek olması peynir gibi sütten elde edilen ürünlerin daha az birim süt ile elde edilmesini sağlamaktadır (Muş İl Gıda Tarım ve Hayvancılık Müdürlüğü, 2015). Bu durum maliyetin düşmesine neden olarak ekonomik bir katma değer oluşturmaktadır. Aşağıda sürdürülebilir bir mera hayvancılığı için yapılması gereken çalışmalar maddeler halinde kısaca yazılmıştır:

(i) İlde, et işleme entegre tesislerinin bulunmaması, yetiştirilen hayvanların il dışına canlı olarak pazarlanmasına neden olmaktadır. Muş'tan her yıl 40 bin civarında büyükbaş ve 80 bin civarında küçükbaşın il dışına canlı olarak sevk edilmesi bu tezimizi doğrulamaktadır (Muş İl Gıda Tarım ve Hayvancılık Müdürlüğü, 2015). Bunun sonucu olarak il, hayvancilıkta yeterince bir katma değer oluşturamamakta ve ayrica sektörün ilde istihdama katkısı daha düşük düzeyde gerçekleşmektedir.

(ii) Son yıllarda özel sektör tarafından özellikle tarımsal sanayi alanında küçük çaplı sanayi tesisleri kurulmaya başlanmıştır. Bu işletmelerin çeşitli teşvik unsurlarıyla desteklenmesi halinde, ilde tarımsal sanayi ve bu sanayiye bağlı yan sanayilerin gelişmesine önemli katkı sağlanabilir (Sanayi Genel Müdürlüğü, 2012: 338-342).

(iii) Doğal mera ve otlak alanlarının bilinçsizce kullanılmasının önüne geçilmesi için çiftçinin bilinçlendirilmesi ve eğitilmesi gerekmektedir. $\mathrm{Bu}$ alanlarda şimdiye kadar olan tahribatı giderici ıslah çalışmaları yapılmalıdır. Bunun için bitki çeşidi ve örtüsünün zenginleştirilmesi çalışmaları Gıda Tarım ve Hayvanc1lık İl Müdürlüğü ve MŞÜ öncülüğünde yapılmalıdır. Ayrıca Doğu Anadolu Projesi Bölge Kalkınma İdaresi Başkanlığı (DAP) tarafından bölgedeki birkaç üniversitede kurulan çiftçi eğitim merkezlerinden de faydalanılabilinir (DAP, 2015)

(iv) Hayvan hastalıkları, hijyen ve kaliteye ilişkin sorunlar ve hayvancilık sektöründe verim düşüklüğü konusunda eylem planlarına gereksinim vardır.

(v) Doğal hayvan potansiyelini değerlendirmek adına hayvan ürünleri OSB kurularak küçük işletmelerin kümelenmesi sağlanabilir.

(vi) Berce Alparslan Tarım İşletmesi yakın zamanda, işletmede hayvancılıkla ilgili yatırım ve çalışmalara başlayacaklarını web sitelerinden ilan etmişlerdir (Berce Alparslan Tarım İşletmesi, 2017b). Bu durum 
özellikle il ve bölgeye uygun verimli büyükbaş ve küçükbaş hayvan yetiştirilmesine katkı sağlayabilir.

\section{Yöresel Ürünlerin Markalaşması Pazarlanması Konusunda Yapılabilecekler}

ve

Doğal gıdada hak edilen katma değeri oluşturabilmek için ilk önce hedef kitleyi tespit etmek gerekmektedir. Hedef kitle, sağlıklı beslenmede doğal gidanın öneminin fakında olan yüksek ve orta gelir sahibi, eğitim seviyesi yüksek bilinçli tüketiciler olup bunların sayıları gün geçtikçe artmaktadır. $\mathrm{Bu}$ kitle doğal gıda sertifikasyonuna sahip ürünlere fazla para verebilecek bir müşteri görüntüsü sergilemektedirler. Doğal gıdanın mera ürünleri gibi birçok kalemi küçük ölçekli aile işletmelerinde üretileceği için doğal gıda sertifikasyonu, ürünlerin tanıtımı ve pazarlanması ancak şemsiye bir kuruluş tarafindan Muş markası adı altında yapıldığında başarılı olabilir. Çünkü bu küçük çaplı aile işletmeleri yukarıda belirtilen işlemleri tek başlarına gerçekleştirebilecek yetkinlikten yoksundurlar ve bu hizmetleri profesyonelce yerine getirebilecek kişi ve firmalara gerekli parasal ödemeyi yapabilecek mali kaynaklara da sahip değillerdir. Ayrıca bu işlemler marka şehir tanıtım ve pazarlama bağlamında organize edilirse daha etkin ve hesaplı olacaktır. Özellikle, mera süt ve et ürünlerinin organik fakat sınırlı bir alanda hareket eden hayvanlardan elde edilen gidalardan daha sağlıklı olduğunu vurgulayan bir tanıtım ve pazarlama yapılmalıdır. $\mathrm{Bu}$, mera ürünlerinin organik etiketli ürünlere göre farkındalığını ve üstünlüğünü göstereceğinden pazarda bir yer edinebilme açısından oldukça önemlidir. Muş'un ürettiği malların ihracatı için ulusal pazar ve komşu Ortadoğu, Avrupa, Ön Asya ve Kuzey Afrika ülkeleri ile marka-şehir konseptinde etkin ve hesaplı inovatif reklam ve tanıtımla birlikte uygun pazarlama stratejisi kurgulanarak bağlantı ve anlaşmalar yapılmalıdır. Üretilen mal ne kadar kaliteli olursa olsun etkin bir tanıtım ve pazarlama sistemi olmadıkça hak ettiği değerde satılamaz. Satılamadığı zaman da sürdürülebilir bir tarım ekonomisi geliştirilemez.

Muş'ta girișimci ruha sahip yeterince birey ve firma olduğu rahatlıkla söylenebilir. Zor şartlar altında ve devletin verdiği hibe destekleriyle küçük çaplı çok sayıda firma ve kooperatifin son üç-dört yıl içinde kurulması bu savımızı desteklemektedir (Muş Gıda, Tarım ve Hayvancılık il Müdürlüğü, 2015; Muş Bilim, Sanayi ve Teknoloji Müdürlüğü, 2015). Ancak bu firmalar veya kooperatifler genelde kurulduktan birkaç yıl sonra kapanmaktadırlar. Bu durum firmaların ürettiklerini satamamaları veya ürünlerini hak ettiği değerde satamamalarından kaynaklanmaktadır. Çünkü Muş ilinin ekonomik pazar potansiyeli küçük olduğundan bu firmaların sadece Muş pazarına mal satarak ayakta kalabilmeleri mümkün değildir. Ayrıca ürünlerinin doğallığıyla pazarda öne çıkarak katma değer oluşturabilmenin öneminin şimdiye kadar farkına varılmamıştır. Bu da doğal gıda üreticilerinin, il içindeki pazarda da markalaşmış konvansiyonel ürünlerle rekabetten dolayı düşük ücretle ürünlerini satmaları sebebiyle piyasada tutunamamalarına neden olmaktadır. Bu yüzden ildeki üreticilerin ülke içi ve dıșına doğal gıda etiketiyle ürün satabilmeyi kolaylaştıracak gerekli sertifikaları bir an önce almaları gerekmektedir.
Kentlerde yaşayan, katkısız gıdaların önemini kavrayan ve gittikçe sayısı artan insanların beklentilerine karşılık verilmelidir. Onlara güvenle yiyebilecekleri gıdaların kapıları açılmalıdır. Aksi takdirde bu alan da büyük ölçekli firmalar tarafından "çeşitli köy ve organik ürün" konseptleriyle doldurulacaktır.

Yöresel doğal ürünlerin katma değer üreterek pazarda yer edinebilmesi için yapılması gereken çalışmaların bazıları aşağıdaki gibi sıralanabilir:

(i) Kente özgü doğal gıda ürünlerin ve türevlerinin coğrafi işaretleri alınmalıdır. Coğrafi işaretlerin alınması ürünlerin iyi bir kalite standardında üretilip korunmasını sağlamanın yanı sıra bu yöresel ürünlerin başka illerce sahiplenilmesini de engellemiş olacaktır. Buna ek olarak coğrafi işaret tescilli ürünlerin yurtiçi ve yurtdışı pazarlarda iyi bir fiyatla müşteriler bulunmasına büyük bir katkısı olacaktır.

(ii) İle özgü coğrafi ürünlerin katma değer üretme ve pazarlanabilme potansiyeline göre öncelikli hale getirilerek markalaşması için çalışmalar yapılmalıdır. $\mathrm{Bu}$ ürünlerin doğallığına zarar vermeden işlenmiş türevlerinin geliştirilip pazarlanması ve tanıtılması stratejilerinin oluşturulması önemlidir. Bunun için fuar, festival, program vs. tanitım faaliyetlerinin düzenlenmesi ve bilinen fuarlara katılmalarının özendirilmesi gereklidir.

(iii) İlde tabii olarak yetişen ve ile özgü doğal ürünlerden (Muş üzümü, güz armudu, macirek elma, doğal semizotu, kenger, hiso, nisan, yaban pancar otu, çă̆ bitkisi, uçkun, güllük, kuş konmaz, lahana, ceviz, kuşburnu, alıç, kızılcık, dut vb.) sertifikalı markalar oluşturulmalıdır.

(iv) Firmaların sertifikasyon ve kalifikasyon işlemleri de göz ard1 edilmemelidir. İşletmelere, gida sağlığ güvenliği açısından gerekli belgelerin alınması konusunda MSKP bünyesinde oluşturulacak bir birim tarafından gerekli yönlendirmeler yaparak ilgili kamu kuruluşlarınca gereken desteğin verilmesi sağlamalıdır.

(v) Muş Sürdürülebilir Kalkınma Platformu çatısı altında ortak bir tanıtım ve pazarlama sistemi geliştirilmeli ve bunu uygulayacak bir pazarlama birimi oluşturulmalıdır. Böylece düşük bir tanıtım bütçesiyle ve daha az maliyetli etkin bir pazarlama sistemiyle ildeki işletmeler için geliştirilme şansı elde edilebilir. Aşağıda bu ortak pazarlama ve tanıtım birimi için bazı öneriler geliştirilmeye çalışılmıştır:

İlk başta ulusal ve uluslararası pazarlara odaklanarak hedef müşteri kitlelerine yönelik araştırmalar yapılmalıdır. Bunun için Türkçe, İngilizce ve hedeflenen ülkelerin dillerinde tanıtım materyalleri hazırlanmalıdır.

- Daha sonra yöreye ait doğal gıda ürünlerinin iç ve dış tüketiminin talebinin arttırılmasına yönelik tanıtım faaliyetlerinin artırılmasına ağırlık verilmelidir.

- İnternet üzerinden pazarlama olanaklarından yararlanılmalıdır. Böylece ilsel derinlikten çok ulusal ve uluslararası derinlik yakalanarak pazarın daha hızlı büyümesi sağlanabilir. Bunun için de kente ait bir e-ticaret platformu oluşturulabilir ve gıda pazarlayan popüler portallerle işbirliğine 
gidilerek ürünlerin burada satılması sağlanabilir. Özellikle Muş ili doğal gida e-ticaret platformu aracılığıyla doğal gıdanın sağlık açısından üstün yönlerine dikkat çekilerek tüm dünyaya hitap edebilen bir satış reyonu oluşturulmuş olacaktır. Böylece fiziki olarak ulaşılamayacak birçok pazara erişim kolaylığı elde edilmiş olacaktır. Bu platform hedeflenen ülkelerin dillerinde hizmet verecek şekilde tasarlanmalıdır.

\section{Sonuç ve Değerlendirme}

Muş'un sosyo-ekonomik durumu, geçmişten günümüze ekonomik gelişim ve sanayileşme çabaları ve SWOT analizi göz önüne alındığında ilin pazarda farkındalık oluşturacak ve ulusal düzeyde markalaşıp yurt dışına açılmasını sağlayacak alanın, doğal tarım ve hayvancılık olduğu açıkça görülmüştür. $\mathrm{Bu}$ potansiyelden sürdürülebilir bir ekonomik gelişim sağlamak için burada belirtilen temel hususların göz önünde bulundurulması gerekmektedir. Bu amaçla ilin doğal tarım ve hayvancılık kapasitesinden maksimum verim elde edilmesi ve doğal tarım ve hayvancılık üretim ortam ve şartlarının korunması için gerekli tedbirler almalı; elde edilen ürünlerin doğallığına zarar vermeden verimliliğini artırabilecek yöntem ve teknolojilerden azami derecede faydalanılmalıdır. Ayrıca ovanın tümünden yararlanabilmek için su taşkınlarını önleyici proje çalışmalarının bitirilmesi, ovadaki düzensiz su rejiminin düzenli hale getirilmesi için drenaj sorununun halledilmesi ve büyük çaplı organik endüstriyel bitkilerin tarımsal üretiminin yapılmasına olanak sağlayan toplulaştırma çalışmalarının acilen bitirilmesi gerekmektedir. Hayvancılıkta ise Muş'un doğasına uygun, verimi yüksek büyükbaş ve küçükbaş hayvanların yetiştirilmesi veya yerli ırkların ıslah çalışmalarıyla daha verimli hale getirilmesi gerektiği görülmektedir. Doğal gıdanın elde edileceği ortamın korunması ve geliştirilmesiyle maksimum verimin temininden sonra bu ürünleri pazarda iyi bir ücrete satabilmek önemlidir.

İnsan sağlığı için faydalı ve çevreyle barışık üretime sahip gıdalardan hak edilen katma değeri üretebilmek için marka şehir bağlamında tanıtım ve pazarlamayı organize edecek bir şemsiye kuruluş oluşturulması gerektiği görülmüştür. Çünkü ilin sermaye yapısı ve özellikle mera hayvancılığının doğası gereği bu sektörde ağırlıklı olarak küçük çaplı aile işletmeleri yer alacaktır. $\mathrm{Bu}$ işletmelerin ulusal ve uluslararası arenada tanıtım ve pazarlama yapabilecekleri ne bir ekonomik güç ve ne de yönetim kapasitesine sahip olmamalarından dolayı bu doğal ürünlerin tanıtım ve pazarlamasının Muş'a özgü bir kuruluş tarafından yapılması gerekmektedir. $\mathrm{Bu}$ kuruluşun ilin şartlarına özel oluşturulabilmesi için dünyadaki iyi örneklerden faydalanılmasına ve pazardaki firsat ve tehditler dikkate alınarak inovatif ve hesaplı bir tanıtım ve pazarlama stratejisi geliştirilmesine gereksinim vardır. Çünkü nitelikli ürün üretmek, onu ekonomik bir değere dönüştürmek anlamına gelmemektedir. Muş'a özgü üretilen sağlıklı ürünleri hak edeceği değerlerde satabilmek için maliyeti az fakat etkin bir tanıtım ve pazarlama sisteminin geliştirilmesi, il için sürdürülebilir bir ekonomik gelişimin anahtarıdır. $\mathrm{Bu}$ nedenle, bu çalışmadan sonra yapılabilecek araştırmalarda marka şehir bağlamında geliştirilecek tanıtım ve pazarlama sisteminin nasıl olması gerektiği konusu üzerine odaklanılmalıdır.
Tabi burada öne çıkan hususlardan birisi de kurulacak işletmelerin ilin beşeri sermaye ve diğer şartları göz önüne alındığında mikro, küçük ve en fazla orta ölçekli işletmeler olacağı gerçeğidir. $\mathrm{Bu}$ firmaların ayakta kalarak gelişebilmesi için sektörel olarak kümelenmeleri gerekmektedir. $\mathrm{Bu}$ durum firmaların fiziki altyapı, ortak pazarlama ve tanıtım gibi bazı ortak hizmetlerinin mali finansmanın bir kısmını hibe desteklerinden ve/veya kendi finansal kaynaklarından daha az maliyetle karşılamalarını sağlayacaktır.

SWOT analizinde dillendirildiği gibi bütünsel bir stratejik planlanma, kaynakların etkin bir şekilde kullanılmasını sağlayarak çıktıyı maksimize eder. Bunun için marka şehir bağlamında oluşturulacak pazarlama ve tanıtım, fiziki altyap1, ilin ekonomisi ve sanayisi için geliştirilebilecek projeler ve merkezi hükümetin desteğini maksimum kılmak gibi çabaların etkin ve hesaplı yapılabilmesi adına Muş'a has kurumsal bir yapıya gereksinim olabilir. Bir çatı kuruluşu olabilecek yapıya bu çalışmada "Muş Sürdürülebilir Kalkınma Platformu" ismi verilmiştir. Bu kuruluşun, bahsi geçen fonksiyonları yerine getirebilecek kapasitede ve yapıda inşa edilebilmesi için ilk olarak platform yapısı ve üyelerinin kimlerden oluşması gerektiği, ildeki tüm kurum ve kuruluşların katılımıyla yapılacak anket, toplantı ve çalıştay gibi kolektif çalışmalarla belirlenmelidir. Daha sonra, kuruluşun yapısının nasıl olması gerektiği, kolektif aklın tezahürünün en üst düzeyde oluşabilmesi için hangi metotları kullanarak çalışması gerektiği ve merkezi otoritenin hangi birimlerinin dış paydaş olabileceği belirlenip tespit edilmelidir.

\section{Kaynakça}

AFAD (2017). T.C. Başbakanlık Afet ve Acil Durum Yönetimi Başkanlığ Deprem Dairesi Başkanlığ Deprem Bölgeleri Haritasl. (Erişim: 17.09.2017), http://www. deprem.gov.tr/tr/kategori/deprem-bolgeleri-haritasi28841

Aro, A., Mannisto, S., Salminen, I., Ovaskainen, M. L., Kataja, V., \& Uusitupa, M. (2000). Inverse Association between Dietary and Serum Conjugated Linoleic Acid and Risk of Breast Cancer in Postmenopausal Women. Nutr Cancer, 38(2),151-157.

Arslan, Ö. (2017a). Kamu, Üniversite ve Sanayi İşbirliğinin Doğu Anadolu Bölgesinin Sanayi Gelişimine Katkıları Üzerine Bir Çalışma. Uluslararası Hakemli Ekonomi Yönetimi Araştırmaları Dergisi, 11, 54-77.

Arslan, Ö. (2017b). Kamu-Üniversite-Sanayi İşbirliği Yapılanma Çalışmalarının Türkiye Sanayisinin Gelişimine Olası Katkıları. Anemon Muş Alparslan Üniversitesi Sosyal Bilimler Dergisi, 5(3), 823-849.

Asi, H. (2012). Muş İlinin Sosyal ve Ekonomik Gelişmesinde Tarım Sektörünün Yeri ve Önemi. Uzmanlı Tezi. Ankara: T.C. İçişleri Bakanlığı Strateji Geliştirme Başkanlı̆̆ı.

Ateş Durç, S. (2009). Türkiye'de Aşiret ve Siyaset İlişkisi: Metinan Aşireti Örneği. Yüksek Lisans Tezi. Ankara: Hacettepe Üniversitesi. 
Bagga, D., Anders, K.H., Wang, H.J., \& Glaspy, J.A. (2002). Long-Chain omega-3 to omega-6 Polyunsaturated Fatty Acid Ratios in Breast Adipose Tissue from Women with and without Breast Cancer. Nutr Cancer, 42(2),180-185.

Berce Alparslan Tarım İşletmesi (2017a). Berce Alparslan Tarım Işsletmesi (Muş) Hakkında Genel Bilgiler. (Erişim: 19.09.2017), http://www.berce.com.tr/nerelerdeyiz/ berce-alparslan-tarim-isletmesi-mus/

Berce Alparslan Tarım İşletmesi (2017b). Berce Alparslan Tarım Işsletmesi Projesi. (Erişim: 19.09.2017), http://www.berce.com.tr/projelerimiz/berce-alparslantarim-isletmesi-projesi/

CHP Doğu ve Güneydoğu Komisyonu (1999). CHP Doğu ve Güneydoğu Raporu. (Erişim: 19.09.2017), https://acikerisim.tbmm.gov.tr/xmlui/bitstream/handle/1 1543/806/200002536.pdf? sequence=1\&isAllowed=y

Couvreu, S., Hurtau, C., Lopez, C., Delaby, L., \& Peyraud, J. L. (2006). The Linear Relationship between the Proportion of Fresh Grass in the Cow Diet, Milk Fatty Acid Composition, and Butter Properties. Journal of Dairy Science, 89, 1956-1969.

Çaha, Ö., \& Tutar, H. (2013). TRA2 Bölgesi'nde Yoğun Kamu Çalışanı Göçü: Sorunlar ve Çözüm Önerileri. Kars: Serhat Kalkınma Ajansı. (Erişim: 19.09.2017), http://www.serka.gov.tr/ru/store/file/common/6c37ba43 764553cd89e02dcf097f9491.pdf

Çaha, Ö., Çaylak, A., \& Tutar, H. (2013). TRA2 Bölgesi Sivil Toplum Kuruluşları Profili. Kars: Serhat Kalkınma Ajans1.

DAKA (2015). DAKA Muş Il Brifingi. Muş: DAKA Muş Yatırım Destek Ofisi.

DAP (2015). DAP Brifingi. Muş: Muş Valiliğii.

Dhiman, T. R. Anand, G.R., Satter, L.D., \& Pariza, M.W. (1999). Conjugated linoleic acid content of milk from cows fed different diets. J Dairy Sci., 82(10), 2146-2156.

Dölek, İ. (2014). Muş Depremleri (Eylül 2013) ve Muş İlinin Depremselliği. Makalelerle Muş, 183-204.

DSİ (2015). DSI 17. Bölge Müdürlüğü Muş Brifingi. Muş: DSİ 17. Bölge Müdürlüğü

Duckett, S. K., Wagner, D. G., Yates, L. D., Dolezal, H. G., \& May, S. G. (1993). Effects of Time on Feed on Beef Nutrient Composition. Journal of Animal Science, 71(8), 2079-2088.

Duckett, S.K., Neel, J.P.S., Fontenot, J.P., \& Clapham, W.M. (2009). Effects of Winter Stocker Growth Rate and Finishing System on: III. Tissue Proximate, Fatty Acid, Vitamin and Cholesterol Content. Journal of Animal Science, 87(9), 2961-2970.

Dünya Gazetesi (2011). Muş'tan Azerbaycan'a mobilya ihracatı. (Erişim: 19.09. 2017), https://www.dunya.com/ gundem/mus039tan-azerbaycan039a-mobilya-ihracatihaberi-146660.

Eatwild (2017). Grass-Fed Basics. (Erişim: 19.09.2017), http://eatwild.com/basics.html
Eden, M. (2015). Sabancı Holding'in Kuruluş Öyküsü ve Yükselişi. (Erişim: 19.09. 2017), http://kimkurdu.com/ sabanci-holdingin-kurulus-oykusu-ve-yukselisi/

Etikan, İ., \& Erkorkmaz, Ü. (2012). Türkiye'de 81 İlde, Şahsa ve Mala Karşı İşlenen Suçlarda 2008 Yılına Ait Adli İstatistiklerin Çok Boyutlu Ölçekleme Analizi ile İncelenmesi. Türkiye Klinikleri Tıp Bilimleri Dergisi, 32, 1295-1306.

FDA (2017a). Eating Fish: What Pregnant Women and Parents Should Know. (Erişim: 19.09.2017), https://www.fda.gov/Food/ResourcesForYou/Consumer s/ucm393070.htm

FDA (2017b). Technical Information on Development of Fish Consumption Advice - FDA/EPA Advice on What Pregnant Women and Parents Should Know about Eating Fish. (Erişim: 19.09. 2017), https://www.fda.gov/ Food/FoodborneIllnessContaminants/Metals/ucm53113 6.htm.

Günaydın Muş Gazetesi (2015). Üniversite’nin Öğrenci Sayısı 10 Bini Geçti. 18 Ağustos 2015 tarihli gazete arşivi. (Erişim: 19.09.2017), http://www.gunaydinmus.com/HaberGoster/110f68c3a6c8-4388-9812-fc153ea41b00/universitenin-ogrencisayisi-10-bini-gecti.aspx

Hallam, D. (2003). The Organic Market in OECD Countries: Past Growth, Current Status and Future Potential. p. 179-186, Organic Agriculture: Sustainability, Markets and Policies, OECD.

Ip, C., Scimeca, J.A., \& Thompson, H.J. (1994). Conjugated linoleic acid. A powerful anti-carcinogen from animal fat sources. Cancer, 74(3), 1050-1054.

Järup, L. (2003). Hazards of heavy metal contamination. British Medical Bulletin, 68, 167-182.

Karayolları Genel Müdürlüğü (2017). Türkiye Karayolları Haritası. (Erişim: 17.09.2017), http://www.kgm.gov.tr/ SiteCollectionImages/KGMimages/Haritalar/turistik.jpg

KOSGEB (2015). KOSGEB Il Müdürlüğ̈̈ 2015 Brifingi. Muş: KOSGEB İl Müdürlüğü.

Kraft, J., Kramer, J. K., Schoene, F., Chambers, J. R., \& Jahreis, G. (2008). Extensive analysis of long-chain polyunsaturated fatty acids, CLA, trans-18: 1 isomers, and plasmalogenic lipids in different retail beef types. Journal of agricultural and food chemistry, 56(12), 4775-4782.

Liebhardt, B. (2003). What is Organic Agriculture? What I Learned from my Transition. p. 31-45, Organic Agriculture: Sustainability, Markets and Policies, OECD.

Mailhes, L. (2011). Drug-Resistant Staph Spells Trouble For Meat Industry. (Erişim: 19.09.2017), http://www.care2 .com/greenliving/drug-resistant-staph-spells-trouble-formeat-industry.html.

Massiera, F, Barbry, P., Guesnet, P., Joly, A., Luquet, S., Brest, C.M., Mohsen-Kanson, T., Amri, E., \& Ailhaud, G. (2010). A Western-like fat diet is sufficient to induce 
a gradual enhancement in fat mass over generations. Journal of Lipid Research, 51, 2352-2361.

McAfee, A. J., McSorley, E. M., Cuskelly, G. J., Fearon, A. M., Moss, B. W., Beattie, J. A. M., Wallace, J. M. W., Bonham, M. P., \& Strain, J. J. (2011). Red meat from animals offered a grass diet increases plasma and platelet n-3 PUFA in healthy consumers. British Journal of Nutrition, 105(1), 80-89.

Mercola (2014). Reasons to Switch to Grass-Fed Beef and Dairy. (Erişim: 19.09.2017), http://articles.mercola.com/ sites/articles/archive/2014/05/21/grass-fed-beefdairy.aspx.

Milliyet Gazetesi (2016). Muş'ta Meyvecilik Geliştirilecek. (Erişim: 19.09. 2017), http://www.milliyet.com.tr/musta-meyvecilik-gelistirilecek-mus-yerelhaber-1216038/.

Milliyet Gazetesi (2017). Muş'ta Uygulamall Bilimler Fakültesi'nin Kurulmasi Resmi Gazetede Yayımlandı. 17.09.2017 tarihli gazete arşivi. Erişim: 29.12.2017), http://www.milliyet.com.tr/mus-ta-uygulamali-bilimlerfakultesi-mus-yerelhaber-2281925/.

MTA (2015). MTA Doğu Anadolu Bölge Müdürlüğ̈̈ Brifingi. Muş: Muş Valiliği.

Muş Bilim, Sanayi ve Teknoloji Müdürlüğü (2015). Muş Bilim, Sanayi ve Teknoloji Müdürlüğü Brifingi. Muş: Muş Valiliği.

Muş Çevre ve Şehircilik Müdürlüğü (2015). Muş Çevre ve Şehircilik Müdürlüğü Brifingi. Muş: Muş Valiliği.

Muş İl Gıda Tarım ve Hayvancılık Müdürlüğü (2015). Muş Il Gıda Tarım ve Hayvancılık Müdürlügü Brifingi. Muş: Muş Valiliği.

Muş İl Kültür ve Turizm Müdürlüğü (2015). Muş İl Kültür ve Turizm Müdürlüğü Brifingi. Muş: Muş Valiliği.

Muş OSB Müdürlüğü (2015). Muş OSB Müdürlüğü Brifingi. Muş: Muş Valiliği.

Muş Ovası Gazetesi (2008). Tam Kapasite Üretimdeyiz. 30 Nisan 2008 tarihli gazete arşivi. (Erişim: 19.09.2017), http://www.musovasi.com/haber/tam_kapasite_uretimde yiz-392.html

Muş Ovası Gazetesi (2010). Bölgesel Olarak Çalışmaktayız. 26 Temmuz 2010 tarihli gazete arşivi. (Erişim: 19.09.2017),

http://www.musovasi.com/haber/ergun_bolgesel_olarak _cal-5887.html

Muş Ovası Tarım ve Hayvancılık Çalıştayı (2017). Muş Ovası Tarım ve Hayvancılık Çalıştayı Kitabı 16-17 Mayıs. Muş: Muş İl Gıda Tarım ve Hayvancılık Müdürlüğü.

Muş Valiliği (2015). 60 Dakikalık Muş Il Brifingi. Muş: Muş Valiliği.

Muş'un Sesi Gazetesi (2016). Vali Yavuz, Tekstil Kent Hayata Geçirilecek. 11 Mart 2016 tarihli gazete arşivi. (Erişim: 19.09.2017), http://www.yenimusunsesi.com/haber/vali-yavuztekstil-kent-hayata-gecirilecek-2749.html
Ökten, S.. (2010). İktidarın Sosyolojik Kimliği: Aşiretlerde İktidarın Biçimi ve Kaynakları. Sosyoloji Araştırmaları Dergisi, 13(2), 183-215.

Plastonline (2013). Muş Plastik ilk ihracatını Suriye'ye yaptı. (Erişim: 19.09.2017), http://www.plastonline.com/musplastik-ilk-ihracatini-suriye-ye-yapti/15/

Robinson, J. (2004). Pasture Perfect: How You Can Benefit from Choosing Meat, Eggs, and Dairy Products from Grass-Fed Animals. Washington: Vashon Island Press.

Robinson, J. (2013). Eating on the Wild Side: The Missing Link to Optimum Health. UK: Little Brown \& Company.

Rule, D. C., Broughton, K. S., Shellito, S. M., \& Maiorano, G. (2002). Comparison of muscle fatty acid profiles and cholesterol concentrations of bison, beef cattle, elk, and chicken. Journal of Animal Science, 80(5), 1202-1211.

Sanayi Genel Müdürlüğü (2016). Türkiye 81 Il Sanayi Durum Raporu. Sanayi Genel Müdürlüğü, s.1029-1043.

Sensoy, S., Demircan, M., \& Ulupınar, Y. (2016). Climate of Turkey. (Erişim: 20.04.2016), http://www.mgm.gov.tr/ files/en-US/climateofturkey.pdf

Sırım, V., \& Çayın, M. (2014). Muş Alparslan Üniversitesi'nin İlin Sosyo-Ekonomik Gelişmesindeki Etkileri Üzerine Teorik Bir Inceleme. Makalelerle Muş, s. 63-76.

Simopolous, A.P., \& Robinson, J. (1999). The Omega Diet. New York: Harper Collins.

Simopoulos, A. P. (2002). The Importance of the Ratio of Omega-6/Omega-3 Essential Fatty Acids. Biomed Pharmacother, 56(8), 365-379.

Siscovick, D. S., Raghunathan, T. E., King, I., Weinmann, S., Wicklund, K. G., Albright, J., ... \& Cobb, L. A. (1995). Dietary intake and cell membrane levels of longchain n-3 polyunsaturated fatty acids and the risk of primary cardiac arrest. Jama, 274(17), 1363-1367.

Sönmez, M. E. (2014). Muş Ovası'nın Tarımsal Potansiyeli ve Arazi Kullanım Arasındaki İlişkiler. Makalelerle Muş, $5-32$

Tanyaş, M., \& Arıkan, F. (2013). Bursa İli Lojistik Merkez Ön Fizibilite Raporu. BUSİAD, 2013.

TKDK (2015). TKDK Muş Il Brifingi. Muş: TKDK Muş İl Koordinatörlüğü

TUİK (2013). Seçilmiş Göstergelerle Muş 2013. Ankara: Türkiye İstatistik Kurumu.

Tuzen, M. (2009). Toxic and essential trace elemental contents in fish species from the Black Sea, Turkey. Food and Chemical Toxicology, 47(8), 1785-1790.

TÜİK (2015). Adrese Dayalı Nüfus Kaylt Sistemi (ADNKS) Sonuçları. Ankara: Türkiye İstatistik Kurumu.

Türkiye Şeker Fabrikaları Anonim Şirketi (2014).Türkiye Şeker Fabrikalar Anonim Şirketi Faaliyet Raporu. Ankara: Türkiye Şeker Fabrikaları Anonim Şirketi.

Yurt Çimento (2015). Hakkımızda. (Erişim: 22.10. 2015), http://www.yurtcimento.com/web/ 
Zhu, H., Xu, Y., Yan, B., Guan, J., Zhou, Q., \& Liang, Y. (2016). Risk assessment of heavy metals contamination in sediment and aquatic animals in downstream waters affected by historical gold extraction in Northeast China. Human and Ecological Risk Assessment, 22(3), 693-705. 